\title{
Corela
}

Cognition, représentation, langage

HS-24 | 2018

Multicultural Spoken English

\section{Segmental and suprasegmental change in North West Yorkshire - a new case of supralocalisation?}

\section{Stephan Wilhelm}

\section{OpenEdition}

\section{Journals}

\section{Electronic version}

URL: http://journals.openedition.org/corela/5203

DOI: $10.4000 /$ corela.5203

ISSN: 1638-573X

\section{Publisher}

Cercle linguistique du Centre et de l'Ouest - CerLICO

\section{Electronic reference}

Stephan Wilhelm, « Segmental and suprasegmental change in North West Yorkshire - a new case of supralocalisation? », Corela [Online], HS-24 | 2018, Online since 19 June 2018, connection on 30 April 2019. URL : http://journals.openedition.org/corela/5203 ; DOI : 10.4000/corela.5203

This text was automatically generated on 30 April 2019

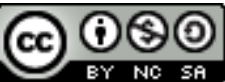

Corela - cognition, représentation, langage est mis à disposition selon les termes de la licence Creative Commons Attribution - Pas d'Utilisation Commerciale - Partage dans les Mêmes Conditions 4.0 International. 


\title{
Segmental and suprasegmental change in North West Yorkshire - a new case of supralocalisation?
}

\author{
Stephan Wilhelm
}

\section{Acknowledgements}

1 The author wishes to thank Mr David Strode, Head of the Languages Department at Guiseley School, Guiseley, for his invaluable assistance in meeting and recording the pupils under his care. He would also like to express special thanks to Olivier Glain and Gabor Turcsan for their help and judicious advice.

\section{Introduction}

2 The diffusion of phonetic and phonological innovations into a number of geographical areas of Britain has lately prompted intensive research into the mechanisms of accent variation and change (e.g. Britain, 2002a, 2002b; Foulkes \& Docherty, 1999; Kerswill, 2002a, 2003 ; Stuart-Smith, Timmins \& Tweedie 2004, 2007, etc.). This paper attempts to further current knowledge about the sociophonetic component of language change. It investigates a number of phonetic and phonological evolutions observed in North-West Yorkshire, and is concerned with apparent-time variation (e.g. Chambers \& Trudgill, 1996 : 76) identified not only at segmental, but also at suprasegmental level. It emphasises the geographical component of sound change and tries to identify some of the psychological factors which contribute to it. The area referred to as North West Yorkshire (NWY from now on) includes Leeds and a mainly rural area comprising the former West Riding County and a small area a few miles north of the Yorkshire Dales. This choice of locations made it possible to narrow down the study of NWY accents to a fairly restricted geographical zone and to compare the data collected in the urban environment of Leeds with features observed in more rural settings. 
3 The outcome of social as well as geographical mobility is dialect contact, which gives rise to two distinct mechanisms observed on a large scale - that is dialect levelling and geographical diffusion, which occur through face-to-face contact and communication accommodation. Dialect levelling consists in a decrease in the number of variants in regional varieties, resulting in the levelling out of differences between dialects (cf. e.g. Britain 2002a, 2002b, 2010). For example, the attrition of the 'Northumbrian burr' - that is the use of uvular variants of $\mathrm{R}$ in Tyneside and adjacent areas - testifies to the operation of dialect levelling in that area of England. Geographical diffusion, by contrast, consists in the dissemination of isolated linguistic innovations into varieties where they have not traditionally been present (cf. e.g. Britain, 2002a, 2002b, 2010). The spread of glottal variants of $\mathrm{T}$ into most contemporary varieties of British English is a well-known instance of geographical diffusion. Dialect levelling and Geographical diffusion combine to favour the formation of new supralocal dialect areas, which are larger than the traditional regions while retaining distinctive characteristics (Williams \& Kerswill, 1999; Britain, 2010).

4 To appreciate the nature and extent of the evolutions observed in NWY as well as the mechanisms underlying their development, we first aim to provide a list of the features thought to characterise Yorkshire accents and identify a number of suprasegmental traits associated with Yorkshire vernacular. We then review a number of phonetic and phonological changes observed at both segmental and suprasegmental levels, as a result of both levelling and diffusion processes. Finally, we discuss some of the issues raised by the attrition of marked variants and the diffusion of innovative features, such as their origins and social significance and their realisational vs. phonological status. We suggest that the situation observed in NWY testifies to the formation of new supralocal accent areas in the north west of England.

\section{Data collection and transcription conventions}

Interviews were arranged with a total of $30 \mathrm{NWY}$ residents, all born and bred in the area. These informants were selected in three age groups -1) over 50 years old, 2) from 30 to 40 years old, and 3) from 9 to 15 years old. Most of the informants were arranged into dyads, and the adolescents aged 9 to 15 were organised into 4 groups of 4 according to their sex and age (2 groups of respectively 12- and 15-year-old girls and 2 groups of respectively 12- and 15-year-old boys). Most of the data were collected in the informants' homes or workplaces using a SONY ${ }^{\circledast} \mathrm{MZ}-\mathrm{RH} 1$ digital recorder and ECM-F8 omnidirectional microphone. The adolescents arranged in groups of 4 were recorded with the same devices in a classroom in Guiseley School's language department. The informants knew that they were being recorded and that they were taking part in a linguistic survey, but were not told beforehand which aspects of their speech would be investigated. Whenever possible, the fieldworker withdrew from the scene in order to prevent any alteration of speech or register due to the observer's paradox (Labov, 1972 : 209). The informants were left to discuss any topic they chose.

6 The data consist of approximately 150 minutes of free conversation in dyads and groups of four as well as approximately 160 minutes of spontaneous teenager interaction in the streets of Leeds and Settle and spontaneous conversation between NWY residents in the presence of the fieldworker. These data were subjected to repeated auditory analysis. A number of innovative vocalic segments and unusual intonation patterns were subjected 
to additional instrumental examination using Praat (Boersma \& Weenink, 2006). Voice quality was investigated using a simplified version of the VPA protocol (Coadou, 2007 ; Laver, 1980, 1994 ; Mackenzie-Beck, 2005 ; Wilhelm, 2011 : 425-437).

7 Whenever possible, the informants were also asked to try and identify, rate and describe 13 different specimens of British English accents ${ }^{1}$ (all taken from the Accent Bank website, ${ }^{2}$ hosting a variety of audio clips featuring the voices of performers from various parts of the United Kingdom).

8 Throughout this study, transcriptions of local vowel pronunciation are provided in terms of Wells' lexical sets, represented by keywords. These keywords are described by Wells (1982 : xviii) as 'intended to be unmistakeable no matter what accent one says them in'. They are traditionally represented in small capitals. Thus, 'the TRAP words' or simply ' TRAP' refers to such words as cat, lap, pad, and 'the TRAP vowel' refers to the vowel heard in these words.

9 This approach has been opted for to avoid arbitrarily choosing the phonemes of one specific accent (like RP) as a comparison basis for the other varieties. When discussing processes (like T-glottalisation, R-labiodentalisation, etc.) or presenting categories, small capitals are also used to represent consonants, following Foulkes \& Docherty (1999). Whenever phonetic transcriptions are provided to illustrate our observations, the first name and age of the informants having produced the transcribed forms are provided in the text of the article, between brackets.

\section{Results}

\section{Traditional features of recognizable Yorkshire accents}

This section aims at providing a list of the most distinguishing features of traditional Yorkshire accents. Some of the distinctive segmental and suprasegmental features of Yorkshire speech are described on the basis of the data collected during this survey, but also with reference to a number of existing descriptions of Yorkshire English, even though these do not necessarily take suprasegmental factors into account.

\section{Segmentals}

11 Chevillet (1986), Petyt (1985), Wells (1982), and Wales (2006) describe a number of 'traditional' segmental characteristics of Yorkshire accents. Analysis of the data for the over-50 age-group yielded results which generally tallied with these descriptions. Traditional features of Yorkshire accents ${ }^{3}$ can be described as follows :

\section{- Vowels}

12 - a very open DRESS vowel ([ع]) (Chevillet, 1986 : 221 ; Petyt, 1985 : 96 ; Wells, 1982 : 364);

13 - an open, sometimes unrounded realisation of Lот ([p] ]) (Chevillet, $1986: 224$; Wells, $1982: 356)$;

14 - the absence of a FOOT-STRUT split ${ }^{4}$ and of BATH broadening (Petyt, $1985: 165,170$; Wells, 1982 : 351-356), as in most northern English accents (e.g. Wales, $2006: 20-24,103$; Wells, $1982: 351)$; 
15 - monophthongal FACE and GOAT vowels ([ẹ:] ; [ọ:] [ọ:]) (Chevillet, 1986 : 226, 228 ; Wells, $1982: 357,364)$;

16 - a very open thought vowel ([ọ:]) (Chevillet, 1986:224; Petyt, 1985:96; Wells, $1982: 360,364)$;

17 - a very narrow PRICE diphthong, with a long, open onset, and an optional very open second element ([a:c] [a'c]), or even a monophthongal PRICE vowel ([a: $]$ ) (Chevillet, 1986 : 227 ; Petyt, $1985: 96$; Wells, $1982: 358,364)$;

18 - a very open, monophthongal SQUARE vowel ([عৃ:] [æ:]) (Chevillet, $1986: 230$; Wells, $1982: 361,364)$;

19 - an open to very open happy vowel ([I] $~[\varepsilon]$ ) (Wales, $2006: 166$; Wells, $1982: 362$ ).

\section{- Consonants}

20 Along with the frequent, vigorous glottalling associated with the Leeds area, ${ }^{5}$ a notable consonantal characteristic of Yorkshire accents is Yorkshire assimilation (Wells, $1982: 367$ ), a form of regressive voice assimilation which causes the devoicing of voiced obstruents when in contact with a following voiceless obstruent across a word or morpheme boundary, and sometimes word-internally (bed time=> ['beditacm]; Bradford => ['bradof $]$ ).

21 In these environments, an underlying / $d /$ can be reinterpreted as a $/ t /$ and realised as a glottal stop (e.g. Bradford => ['bra?fəd], old people $=>$ ['ölP ' $\mathrm{p}^{\mathrm{I} i p 1]) .}$ 'Middle' variants of L, whose perceptual quality is intermediate between clear and dark (Wells, $1982: 370-371$ ), are also observed in prevocalic position.

\section{Suprasegmentals}

To our knowledge, no distinctive study of NWY prosody has been carried out so far. A number of suprasegmental features, however, have to be taken into account in order to account adequately for the distinctive character of Yorkshire accents.

Some remarkable innovative intonation patterns are observed in the lowest age bracket. They will not be described here as this section is concerned with traditional Yorkshire speech. ${ }^{6}$ No particular intonational feature seems to be associated with Yorkshire accents, either in existing descriptions of Yorkshire accents ${ }^{7}$ or in the over-50 age group.

Like Laver $(1980,1994)$ and Mackenzie-Beck (2005), but unlike other researchers (e.g. Marasek, 1997), we consider that voice quality results from both articulatory and phonatory settings. Articulatory settings (also referred to as supralaryngeal settings) consist in the long-term position of the speech organs situated above the larynx as well as that of the larynx and pharynx. By contrast, the phonatory component of voice quality results from phonation types, that is specific modes of vibration of the vocal folds (Laver, 1980, 1994 ; Mackenzie-Beck, 2005).

No characteristic voice quality features of Yorkshire accents seem to have prompted much comment so far. We nevertheless suggest that specific voice-quality settings are associated with traditional NWY speech at both articulatory and phonatory levels : 


\section{- Articulatory settings} This is the case as far as DRESS, SQUARE, TRAP, LOT, THOUGHT, and happY are concerned. In the absence of BATH broadening, TRAP is also distinctly more open than its southern equivalent (Wells, 1982 : 356). In NWY and in other areas of England which Wells calls the English 'Middle North', monophthongal variants of FACE and GOAT are also more open than their equivalents in most Scottish accents ${ }^{8}$ (cp. Wells, 1982:357, 364 and Wells, $1982: 399-400)$. The data collected in this survey also show that :

- KIT is frequently more open than its RP equivalent, although closer variants do occur. Instances of [ë] [媦 [e] are sometimes observed in accented as well as unaccented position : e.g. lift $=>$ ['lẹft] ; six $=>$ ['sẹks] (Christian, 12) ; big $=>$ ['bẹe] (Hannah, 15) ; tripped $=>$ ['trẹpt] (Georgina, 15), Elvis ['Eָlvẹs] (Eleonor, 12).

- Open variants of ғоот frequently occur in all age brackets (e.g. good => ['göd] (Bob, teenager recorded in the street) ; good $=>$ ['gö:d] (Sally, 32)).

- Very open realisations of FLEECE are observed in all age brackets. FLEECE has diphthongal variants with a very open, fronted onset. ${ }^{9}$ (e.g. Leeds $=>$ ['ləIdz]).

29

- GOOSE is sometimes very open. This applies to its monophthongal as well as to its diphthongal realisations (e.g. : schools => ['skọ:z] (Lily, 9); cool => ['kə̈̈̈l] (Bob, teenager recorded in the street)).

Fig. 1 : Vowel chart for the (relatively ${ }^{10}$ ) pure vowels of RP (following Cruttenden, 2001a : 91-148)

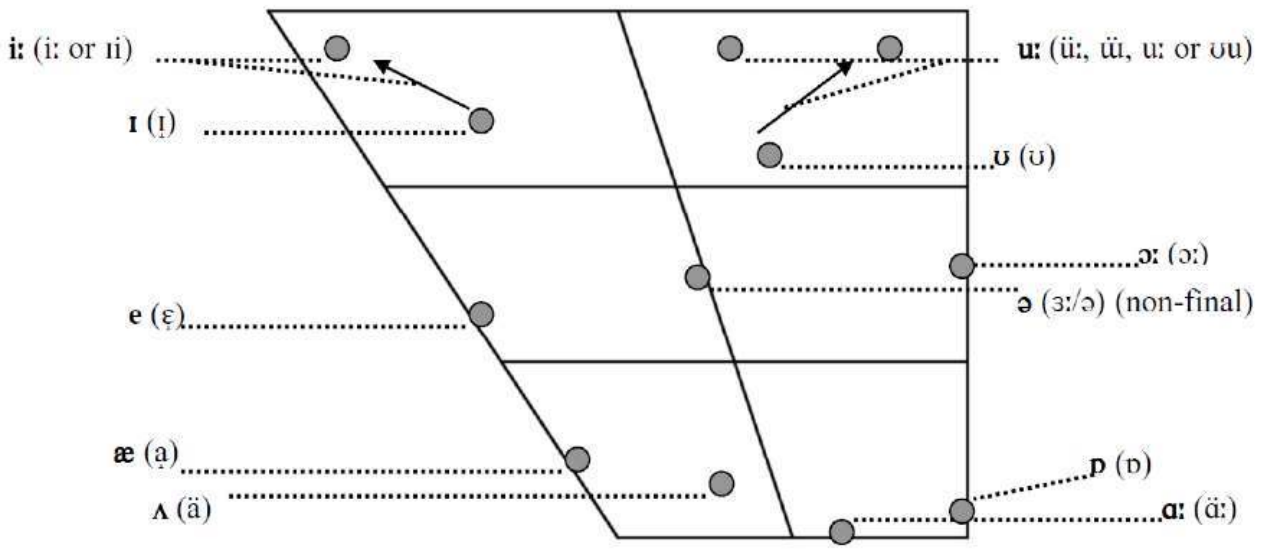


Fig. 2 : Vowel chart for the (relatively) pure vowels in NWY

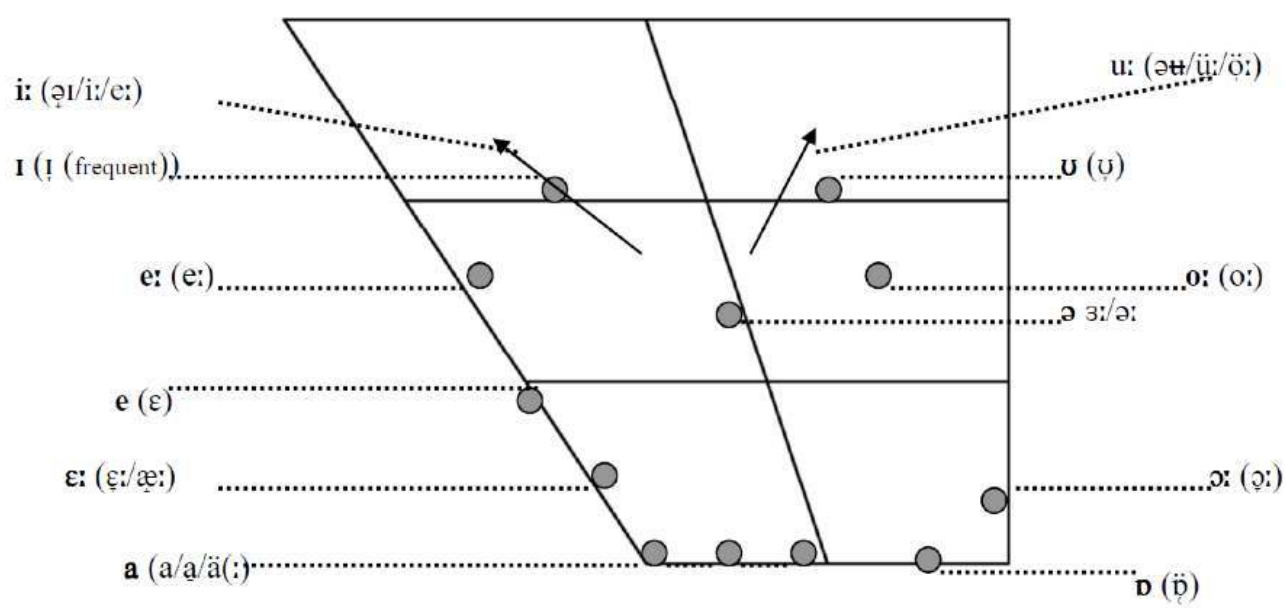

30 As the vowel charts which feature the (relatively) pure vowels of RP and NWY accents show (fig. 1 and 2), not only are a significant number of vowels more open in NWY than in $\mathrm{RP}$, but a noticeable symmetry is also apparent in the NWY vowel system. This is all the more remarkable if one considers that the true front equivalent of the long vowel of THOUGHT is not the short vowel of DRESS, but the long monophthongal vowel of SQUARE. It is thus the whole NWY vowel system that seems to be compressed downwards. This, according to Laver (1994 : 410-411), signals a low tongue-body setting :

Taking the highest point of the tongue body as a point of location, settings of the body of the tongue can be described in terms of the movement of the long-term average position of this point away from its location in the neutral setting. This can be done in two dimensions, vertical and horizontal, so that the body of the tongue can show a fronted or a backed setting, or a raised or a lowered setting. All this will result in a manipulation of the vocoid space [...]; [A] raised tongue-body setting compresses the vocoid space towards the palate, and a lowered tongue-body setting expands the vocoid space downwards. (Italics mine.)

The downward expansion of the vocoid space suggests that NWY accents are characterised by long-term lowering of the tongue-body. This illustrates a principle described by Laver (1994: 404), according to whom the vocalic system of a given accent can be defined in terms of an articulatory setting. ${ }^{11}$

\section{- Phonatory settings}

29 out of 30 speakers are observed to use a significant amount of creaky voice..$^{12} 8$ out of 30 informants, 7 of whom are males, are also observed to use creaky voice almost as their default phonation type. A comparison of these data with Coadou (2007) suggests that NWY speakers of both sexes and in all age brackets tend to use creaky voice more markedly and to a greater extent than speakers using other accents of English. This tallies with the findings of Coadou (2007: 184-196) and Henton \& Bladon (1988), who have shown that northern speakers of English English tend to use creaky voice more extensively than Southerners. Creak and creaky voice are normally associated with a low register (50 to $100 \mathrm{~Hz}$ for 'pure' creak), and it is not without interest to note that, when mimicking Southerners, Yorkshire speakers usually use higher voice pitch than in normal speech situations (Daniels, personal communication). Although no definite explanation can be offered for NW Yorkshire speakers using a greater amount of creaky voice than speakers 
of other varieties, it may be suggested that the somewhat uncouth manliness sometimes associated with Yorkshire people (cf. e.g. Howse, 2014) may to some extent be related to this prolific use of creak. Although this would accord with Ohala's (1983) well-known claim that high frequency ultimately signals smallness and a submissive attitude whereas low F0 conveys largeness and self-confidence, we are fully aware that it remains a very tentative and disputable explanation.

\section{Summary}

Judging from auditory analysis of the data as well as from existing descriptions of Yorkshire accents, it seems that NWY accents are characterised not only by a number of segmental (vocalic and consonantal) features, but also by a particular voice quality defined, at articulatory level, by a low position of the tongue-body and at phonatory level, by frequent and marked use of creaky voice.

\section{Innovations and change}

Having listed a number of distinctive features associated with Yorkshire accents, we now describe noticeable changes and innovations observed during this survey. These are observed not only at segmental, but also at suprasegmental level.

\section{Segmental features}

\section{- Vowels}

The vocalic changes observed in NWY are of two types. Some result from the attrition of a number of traditional phonemes and phonemic contrasts and are clearly the outcome of dialect levelling (Trudgill 1986 : 98). Other changes affect the phonetic quality of certain vowels. Whether these are to be attributed to dialect levelling or to the geographical diffusion of isolated features will be discussed in the section devoted to the geographics of accent change (cf. 4.1).

The data testifies to the attrition of a number of traditional phonemes or vocalic contrasts, which used to contribute significantly to what Chevillet (1986) defined as the 'systemic complexity' of Yorkshire phonology. Thus, no instances of the MANE/MAIN ${ }^{13}$, NOSE/KNOWS ${ }^{14}$ or MEET/MEAT ${ }^{15}$ contrasts still regularly attested a few decades ago in Yorkshire vernacular (Chevillet, $1986: 225-226$; Wells, $1982: 357-364$ ) are observed in any age-group, ${ }^{16}$ although the very open onset in a number of diphthongal variants of FLEECE $(3.2 .1$, a) may be a vestige of the MEET/MEAT opposition. Nor is there any trace of the traditional /ov/ phoneme within the THOUGHT lexical set, of /oə/ in FORCE, or / $\mathrm{J} /$ in words spelled with <au $>/<$ ou $>+<$ gh $>$ (Chevillet, 1986:231; Wells, 1982:358). The traditional /ru/ diphthong, which used to mark a phonemic contrast between words like threw and through, exceptionally occurs in some Goose words in the data for Michael (62), but does not signal any actual phonological opposition, occurring for instance in school => ['skiül], but not in threw $=>$ [n

While the changes listed above probably result from the somewhat long-term, gradual attrition of traditional vernacular features (Chevillet, 1986:225-232; Wells, 1982 : 357-364), other changes would seem to consist in the outcome of more dynamic and recent processes (cf. e.g. Wales, 2006). These mainly consist in the emergence of non- 
traditional vocalic features, mostly in the lower age group. A direct comparison between the 9-to- 15 and the over-50 age brackets proves most revealing in this respect.

1. Diphthongal realisations of the two long close-mid vowels (FACE and GOAT) are frequently observed in the 9-to-15 age group, whereas monophthongal variants are the more frequent in the over-50 age bracket (fig. 3, 4, 5, 6, 7, 8) ${ }^{17} \mathrm{~A}$ few monophthongal, fronted variants of GOAT $([\Theta])$ are also observed in the teenagers' speech. ${ }^{18}$

Fig. 3 : Spectrogram of a monophthongal FACE vowel (Elaine, 57)

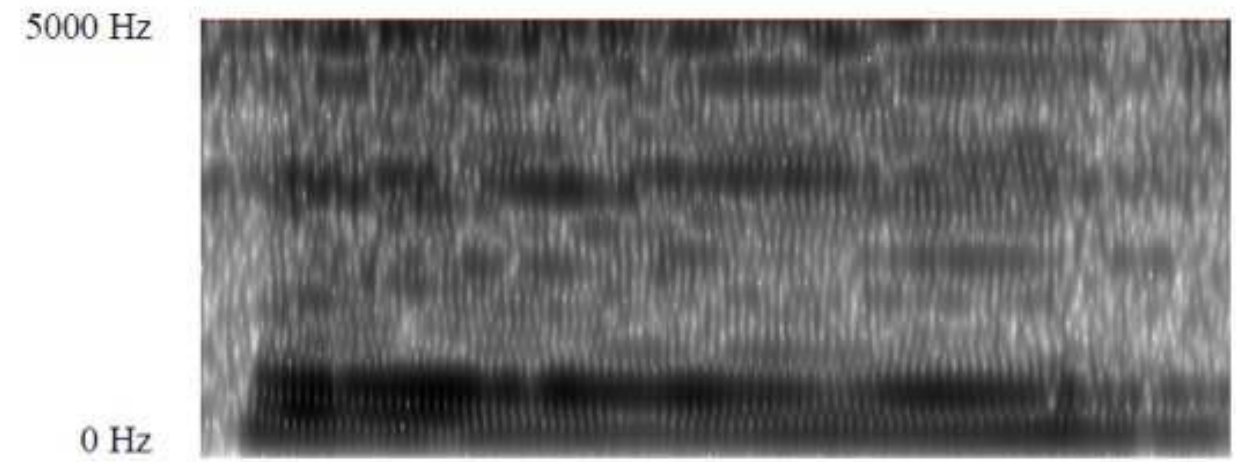

Fig. 4 : Spectrogram of a diphthongal FACE vowel (Hannah, 15)

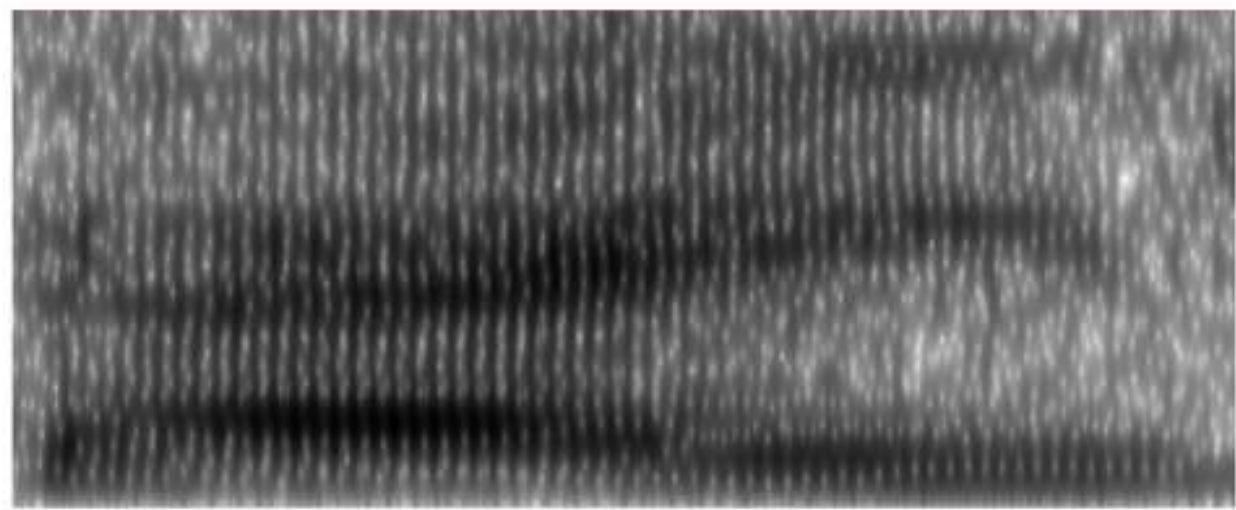

Fig. 5 : Spectrogram of a monophthongal GOAT vowel (Elaine, 57)

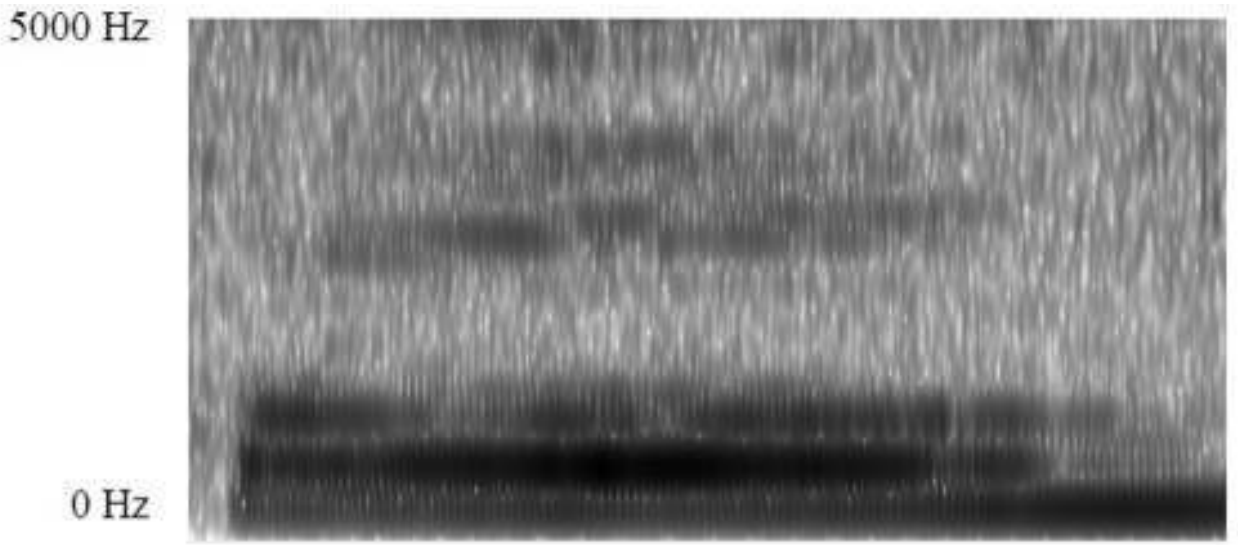


Fig. 6 : Spectrogram of a diphthongal GOAT vowel (Hannah, 15)

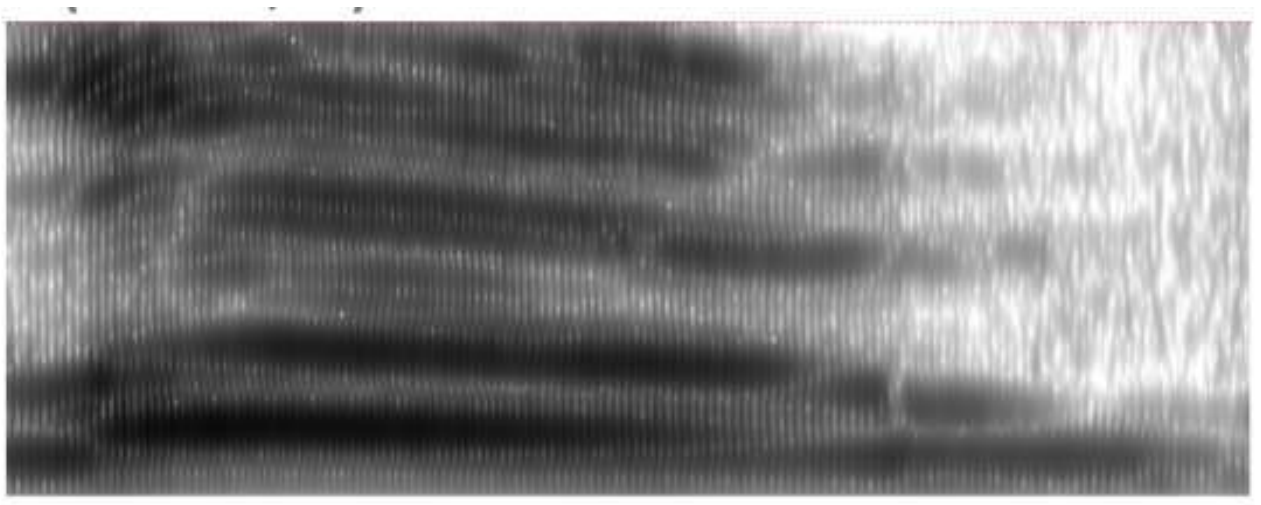

2. Whereas a majority of PRICE monophthongs or narrow diphthongs with a long onset occur in the over-50 age group, most variants observed in the 9-to-15 age group are diphthongs with a shorter onset and closer second element (fig. 9, 10,11). 3. Most happy variants in the over-50 age are open to very open ([I], [I] or even $[\varepsilon]$ ), but close and diphthongal realisations ([i] ; [ع̇ ] [ [ii]) predominate in the 9-to-15 age bracket (fig. 12). Again, this seems to signal change in progress.

Fig. 7 : FACE - \% diphthongal variants per age bracket (p. $<0.01)$

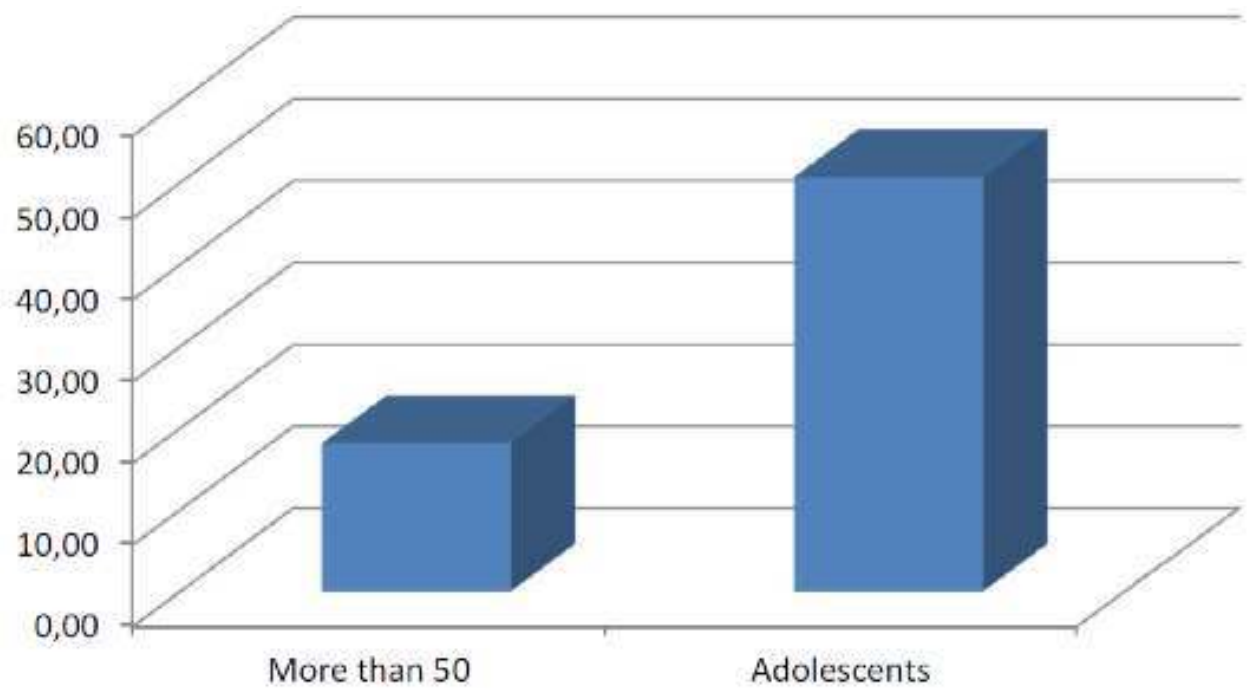


Fig. 8 : GOAT - \% diphthongal variants per age bracket (p. $<0.01)$

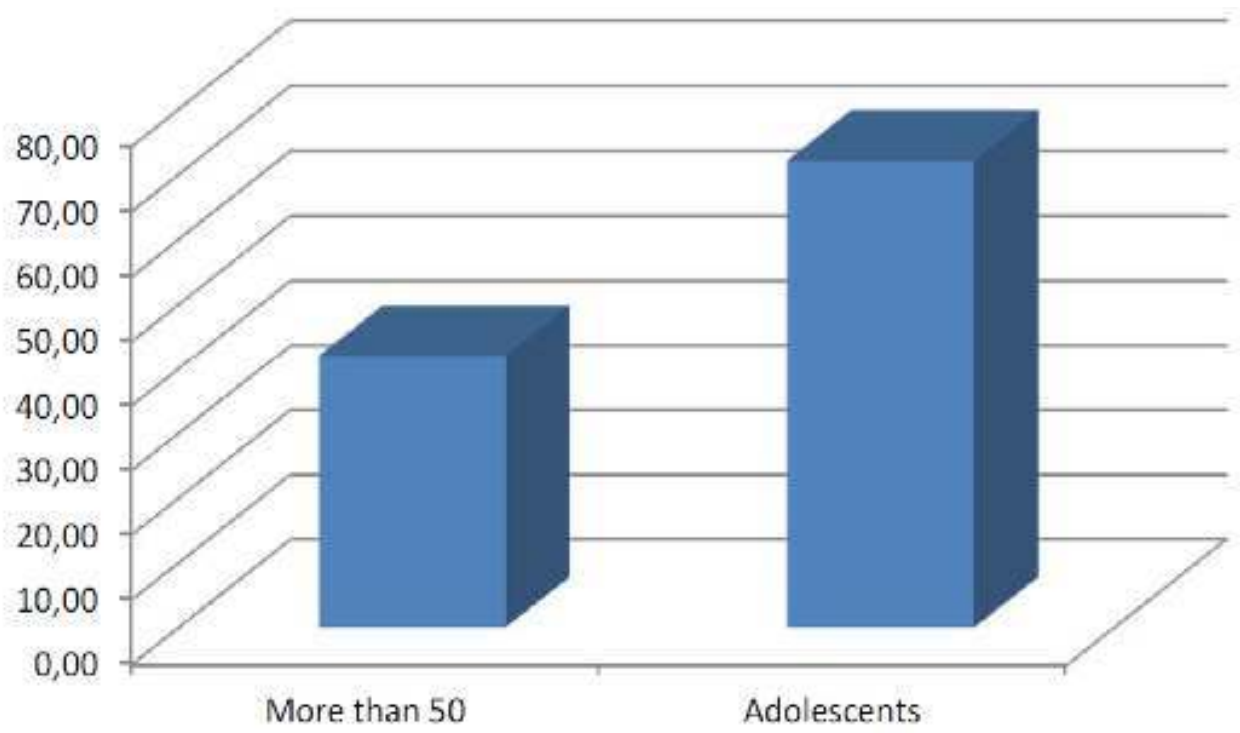

Fig. 9 : Spectrogram of a monophthongal PRICE vowel (Elaine, 57)

$5000 \mathrm{~Hz}$

$\mathrm{OH}_{7}$

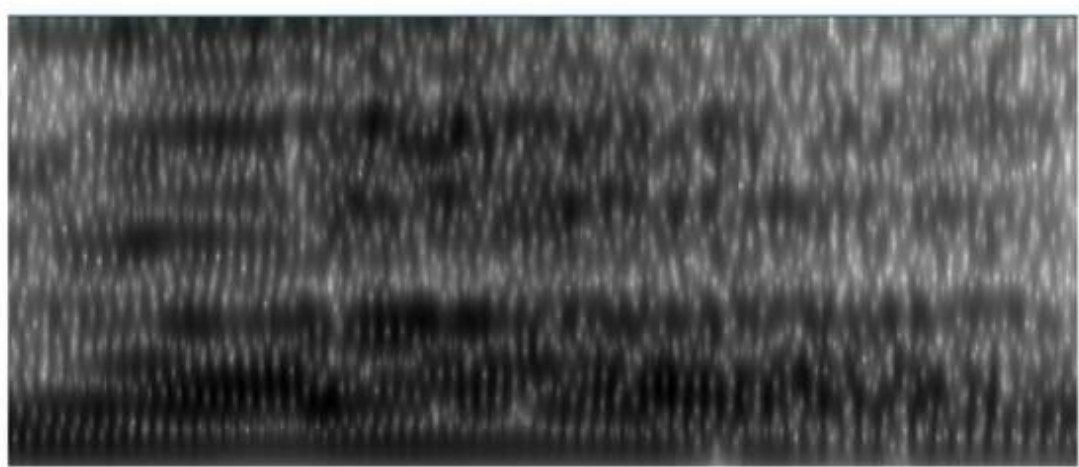

Fig. 10 : Spectrogram of a diphthongal PRICE vowel (Rhys, 12)

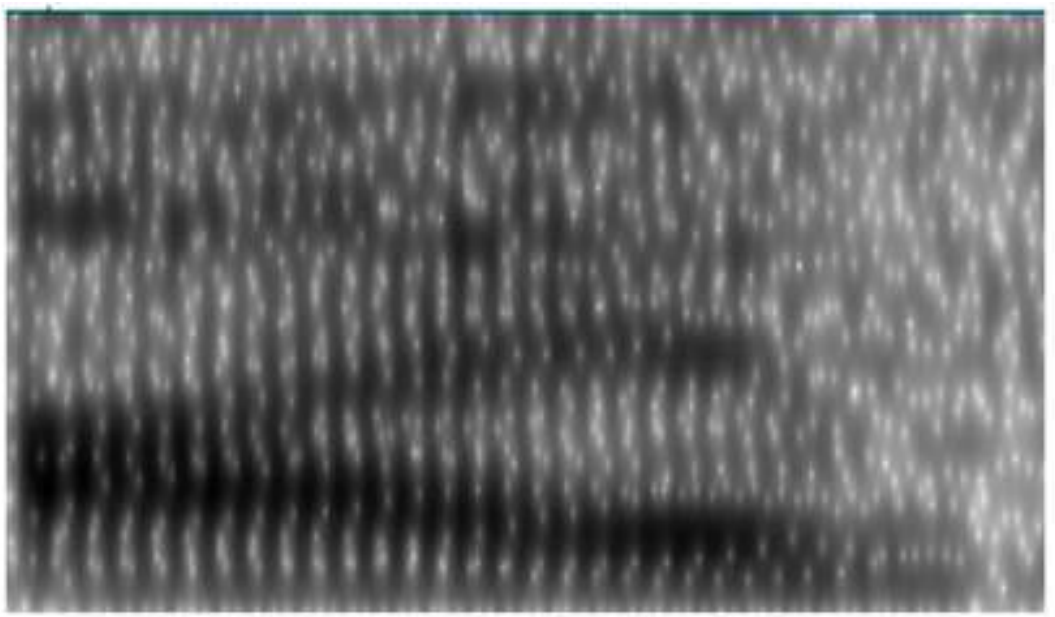


Fig. 11 : PRICE - \% diphthongs with short onset per age bracket $(p .<0.001)$

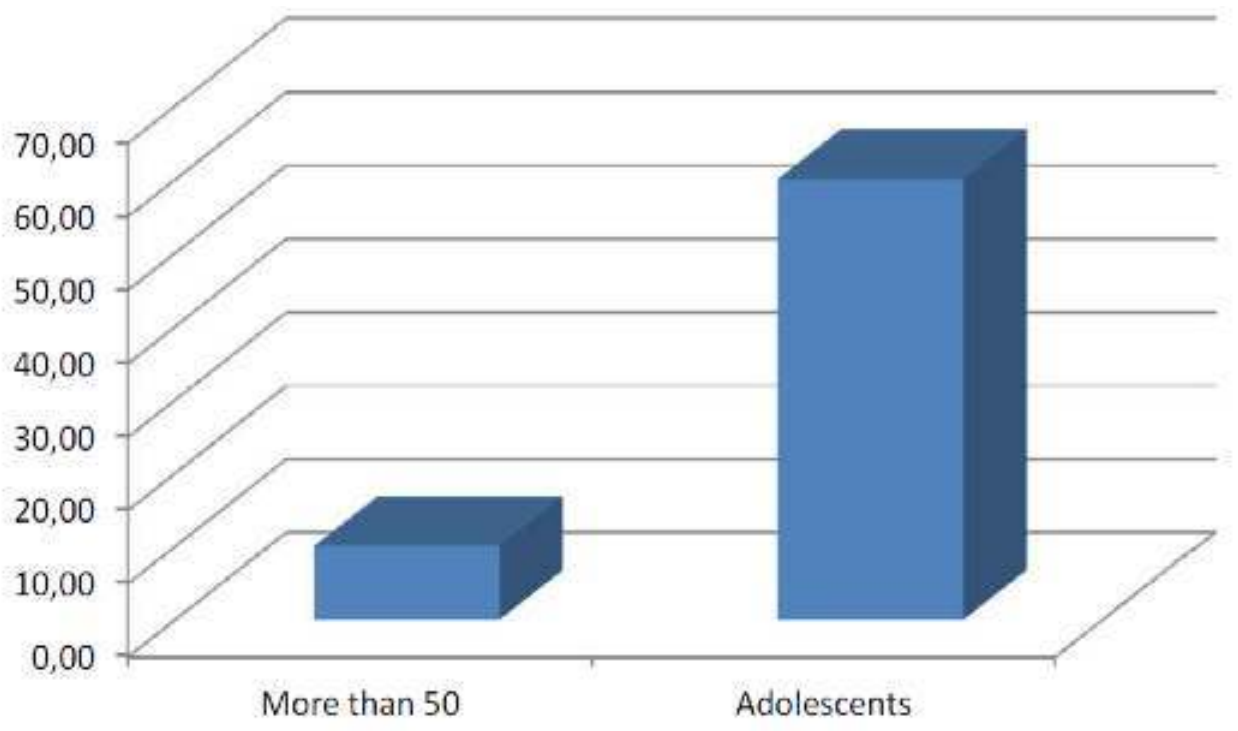

Fig. 12 : HappY $-\%$ close variants per age bracket $($ p. $<0.01)$

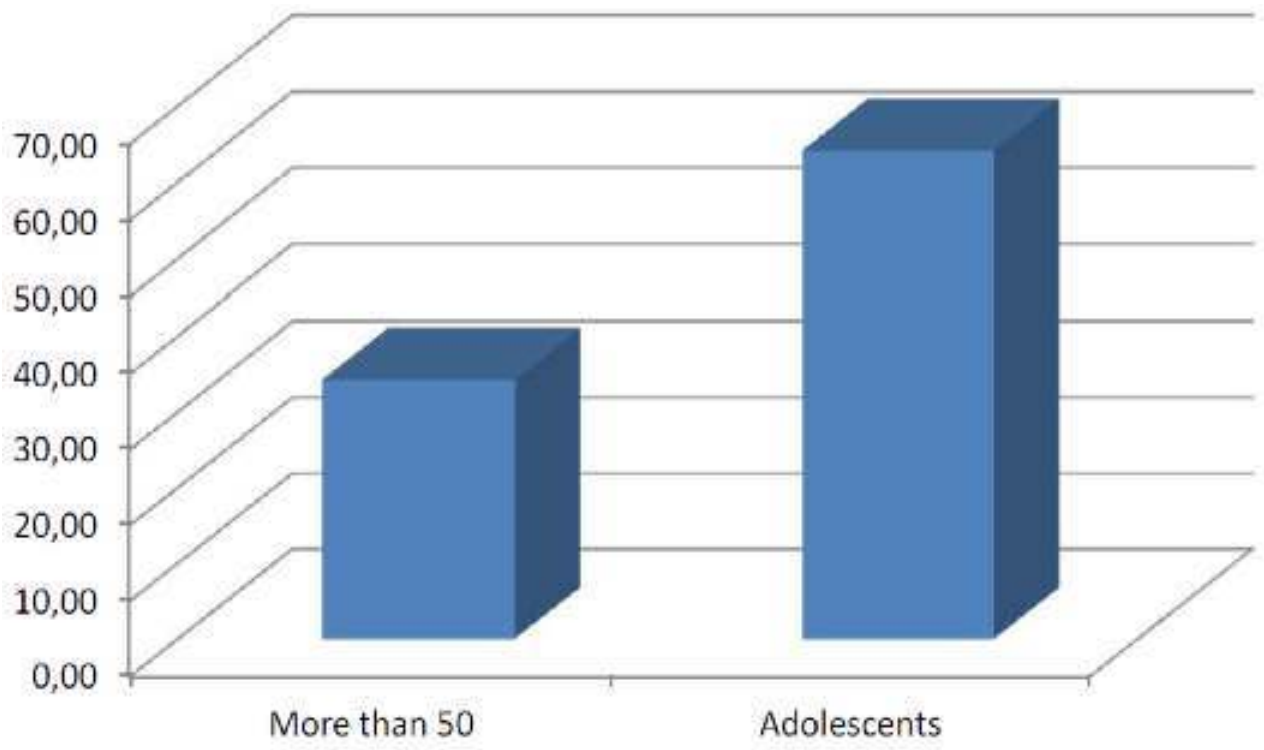

\section{- Consonants}

With the pressure of dialect levelling (e.g. Kerswill, 2002a, 2003) and the development of 'new modern dialects' (Trudgill, 2001:180), such traditional consonantal features as Yorkshire assimilation and 'middle' variants of prevocalic L (cf. section 3.1.1) may have been expected to recede, the more so as the consonantal systems of most accents of British English are thought to be converging (Williams \& Kerswill, 1999 : 147). However, no regression of Yorkshire assimilation was perceived in the 30-to-40 and 9-to-15 age brackets. The phenomenon is indeed very frequently observed in teenage speech in sequences like old people or Bradford, with occasional glottal replacement of the underlying /d/. 

after the TRAP vowel. These variants are realised with a velar fricative (e.g. back $\Rightarrow>$ ['ba $\left.{ }^{x} \mathrm{k}\right]$ (Tim, teenager recorded in the street) back $\Rightarrow>$ ['ba $\left.{ }^{x} k\right]$ (Hannah, 15); tackled $\Rightarrow>$ ['tax $\left.{ }^{x} k ł d\right]$ (Brian, 12) ; racket => ['Jaxk̦̦?] (Christian, 12)). These will be discussed later on.

\section{Suprasegmental features}

42 In addition to the evolutions observed at segmental level, a number of changes also appear to be in progress at suprasegmental level. These innovations affect voice quality or involve the diffusion of non-traditional intonation features.

\section{- Voice quality innovations}

11 informants, all in the 9-to-15 age bracket, are observed to use at least intermittently a raised and retracted position of the tongue body, producing velarised voice. ${ }^{20}$

Fig. 13 : Proportion of informants using velarised voice

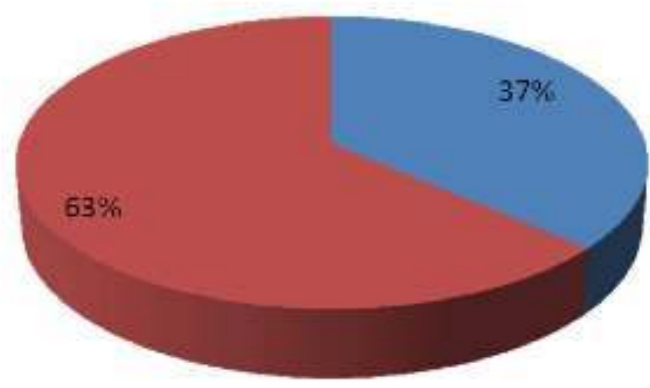

- Informants using velarised voice $(11 / 30)$

Informants not using velarised voice $(19 / 30)$ 
Fig. 14 : Proportion of informants using velarised voice in the 9-15 age bracket

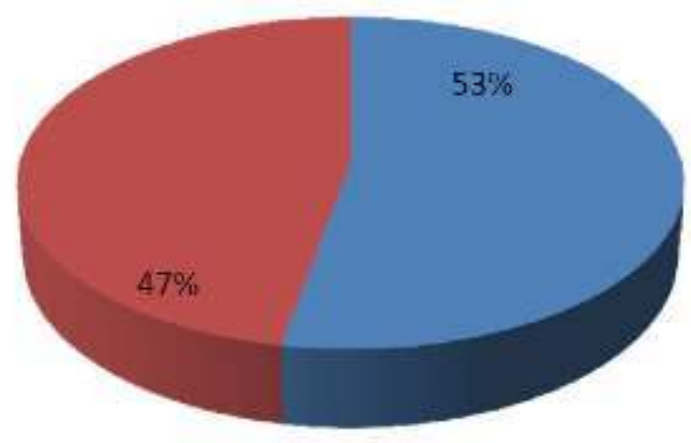

9-15 bracket : informants using velarised voice $(9 / 17)$

9-15 bracket : informants not using velarised voice $(8 / 17)$

Henton \& Bladon (1988) and Stuart-Smith (1999) have shown that the use of voice quality features can be a social identity marker. In the present case, intermittent use of velarised voice seems to be age-conditioned and/or point to change in progress, since no instance of such velarisation is observed in the over-50 age group.

\section{- Intonational change in progress}

Whereas no notable differences between NWY and RP intonation (henceforth RPI, cf. Cruttenden, 2007:261) have been reported in the literature so far (Cruttenden, 2007 : 272 ; Grabe, 2002, 2004 ; Grabe, Kochanski, \& Coleman, 2005 ; Grabe \& Post, 2002), ${ }^{21}$ numerous unexpected intonation patterns were observed in both Leeds and the rural areas. These mainly consist in rising nuclear accents at the end of declarative utterances, mostly in the 9-to-15 age bracket. ${ }^{22}$

A classification of these rising tones is here proposed according to two phonetic criteria amplitude and contour shape.

\section{- Type-1 tones}

These usually start low in the speakers' range and then rise sharply to the end of the phrase, with a contour which may drop imperceptibly before the rise. The rising part of the contour often spans at least $80 \mathrm{~Hz}$, and sometimes up to $275 \mathrm{~Hz}$ (fig. 15). This type of rising tone corresponds to what Cruttenden $(1997: 52 ; 2007: 264)$ calls full rises. It is sometimes observed in portions of speech which also feature high rises and fall-rises at the end of statements, whose rising section spans a narrower range than the rises described above (approximately $40 \mathrm{~Hz}$ ). Impressionistically, the full rises are characterised by their '“querying" nature' (cf. Cruttenden, $2007: 264)^{23}$, and testify to the diffusion of the High Rising Terminal - or HRT - in NWY (cf. Cruttenden, $2007: 270$ ). 
Fig. 15 : Type-1 tone (full rise) (Sally, 32)

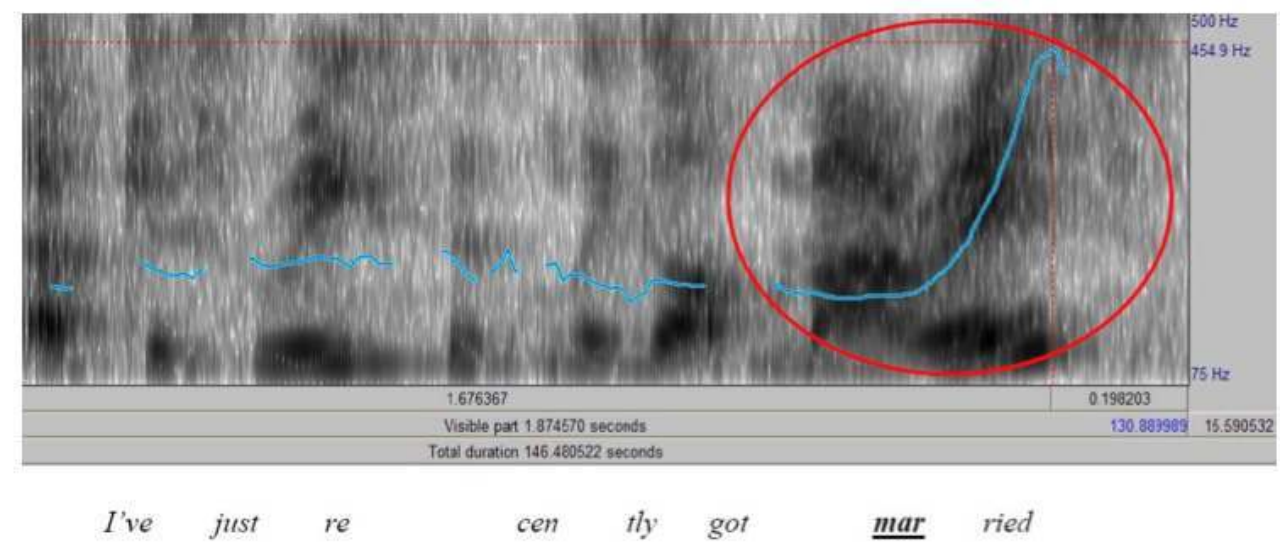

Fig. 16 : Type-2 tone (low rise) (Bob, teenager recorded in the street)

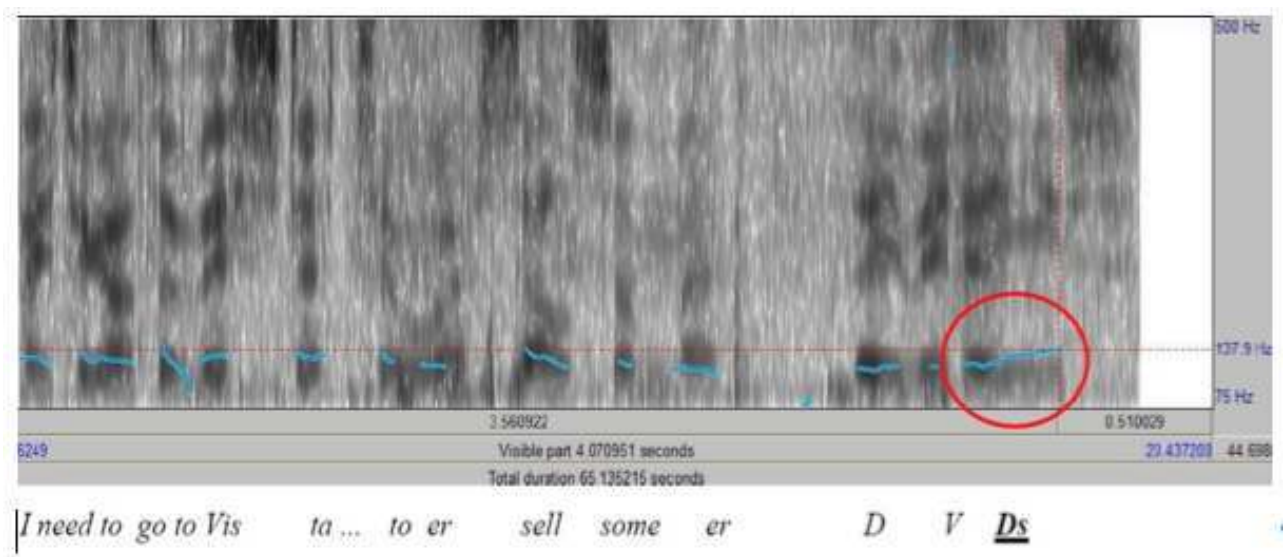
intonation group (which may or may not be preceded by a step down) and rises slightly or very slightly from that low. These rising tones are low rises (Cruttenden, 1997:51, 2007 : 264). Very often they start near the speaker's baseline and may span no more than 5 to $20 \mathrm{~Hz}$ (fig. 16). In some cases, it is difficult to distinguish between type-2 and type-1 contours on purely phonetic grounds. This occurs when the rising part of the pattern spans more than $40 \mathrm{~Hz}$. Type-2 rises are impressionistically different from type-1 rises in so far as they are not generally of a "'querying" nature'.

51 Type-2 tones are not HRTs. Rather, they characterise Urban North British Intonation, or UNBI (Cruttenden, 2007), which Cruttenden $(2007: 257,271)$ defines as 'an intonational system that operates in a number of cities in northern Britain [...] characterised by a default intonation involving rising or rising-slumping nuclear pitch patterns'. Cruttenden often observes an alternation of UNBI and RP intonation (henceforth RPI) in the speech of the same informers (Cruttenden, 2001b, 2007 ; Wilhelm 2015).

- Type-3 tones (compound tones)

These patterns comprise contours which usually begin low to mid on the main accent of the intonation group according to the degree of speaker involvement, with a rising nuclear accent and a 'slumping' - that is, according to Cruttenden's (2001b, 2007) 
terminology, slightly falling - tail. The rising part of the contour may sometimes span as little as $15-20 \mathrm{~Hz}$, and its slumping section no more than $10-12 \mathrm{~Hz}$ (fig. 17). This corresponds to what Cruttenden (2001b : 57-59, $2007: 258)$ calls rise-slumps. ${ }^{25}$

A number of rise-falls, where the pitch returns to the speakers' baseline (fig. 18), are also observed at the end of declaratives where RP speakers would have used simple falls. Differences in F0-syllable alignment also contribute to differentiating these contours from RP rise-falls.

Fig. 17 : Type-3 tone (rise-slump) (Andrew, 15)

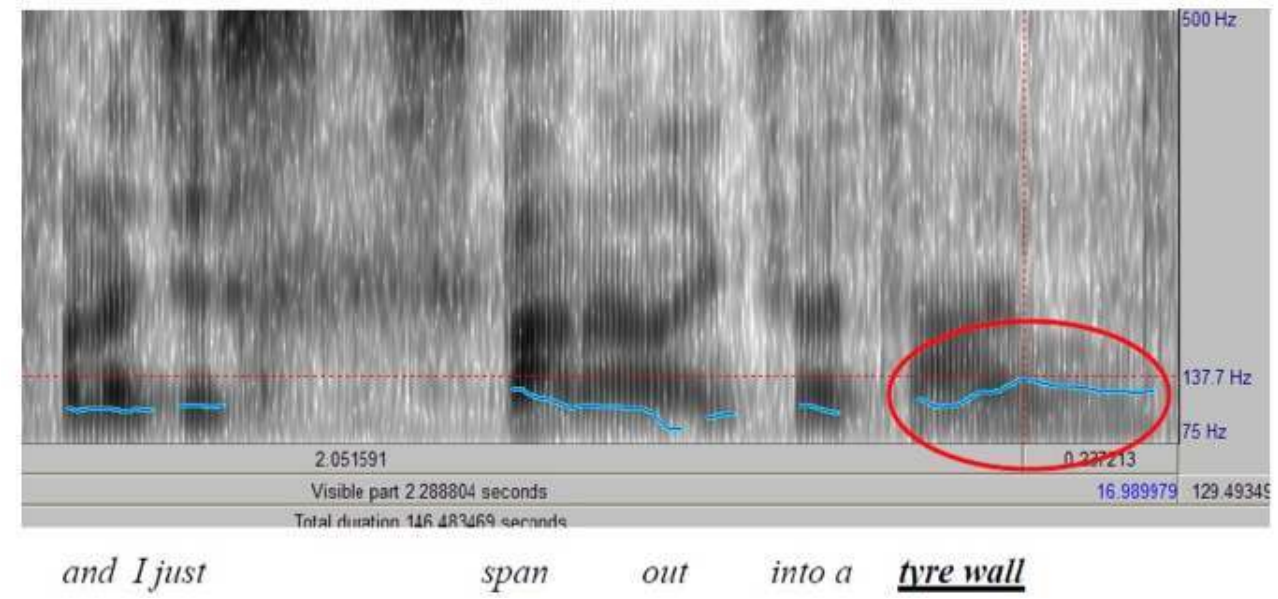

Fig. 18 : Rise-fall (Katrina, 12)

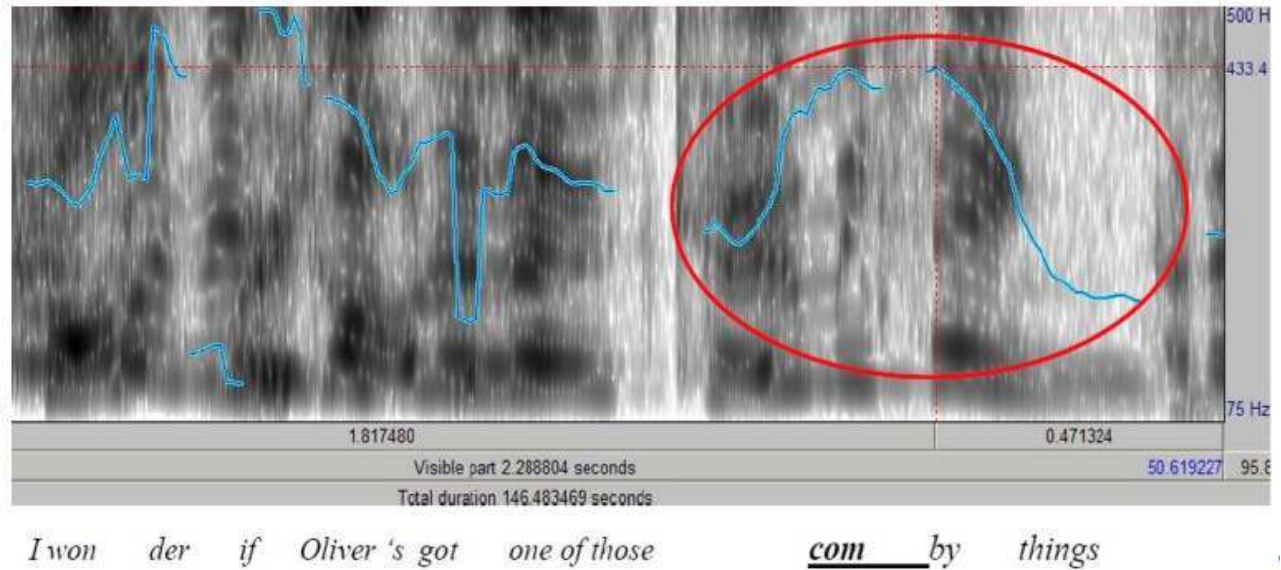

55 Like type-2 contours, rise-slumps and rise-falls are specific to UNBI (Cruttenden, $1994: 261$, 2007:257, 271; Ladd, 1996:124, 143-7; Mayo, 1996:1; Wilhelm 2015). Contrary to what applies to HRTs and to at least some of the type-2 rises, however, there are indications that they may have been present in NWY for longer than what existing descriptions of Yorkshire accents suggest, especially among teenagers and perhaps as a working class feature (Beal ; Cruttenden ; Daniels, Kerswill, personal communications).

As stated above, the presence of type- 1 tones (full rises) in the data testifies to the spread of HRTs to NWY. Although rise-slumps and rise-falls (that is, type-3 tones) are properly falling tones, they involve a nuclear rise, and their frequent use at the end of declaratives is characteristic of UNBI. Type-2 rises are probably not a homogeneous category; 
whereas some of them are undoubtedly UNBI tones, others may be HRTs. Others seem hard to classify. ${ }^{26}$ Whereas it is difficult to determine how long type-3 contours have been present in NWY, it seems clear that type-1 patterns are innovative there (Daniels, personal communication). The same probably applies to type- 2 contours.

\section{Provisional conclusion}

NWY accents are presently undergoing various evolutions, although apparent-time studies do not give any indication as to the potential transience or permanence of the changes observed. Adolescents are likely to be versatile speakers and the features they adopt in their teenage years may be abandoned when they reach adulthood (Chambers \& Trudgill, 1998 : 77-79, 152-159; Wilhelm, 2011 : 492).

What is interesting is that the new developments occur at both segmental and suprasegmental levels. Whereas most studies of language change tend to focus mostly on syntactic, lexical and phonetic/phonological innovations, prosodic change is a domain that has largely remained underexplored. The NWY data suggests that this is a field calling for further investigation. This applies not only to intonation, but also to innovative features of voice quality.

\section{Analysis and discussion}

This section addresses some of the issues raised by the evolutions identified in NWY. It first explores the geographical dimension of the phenomenon and the psychological factors accounting for the spread of the non-traditional features before discussing the implications of the phonetic vs. phonemic status of the diffusing variants.

\section{The geographics of accent change}

The influence of RP has sometimes been alleged to explain such changes as the progress of diphthongal FACE and GOAT in Yorkshire (Chevillet, 1986:25; Wells, 1982:357 ${ }^{27}$ ). However, very different hypotheses have also been proposed to account for similar changes elsewhere, such as the influence of the media (Stuart-Smith \& Timmins, 2005) or diffusion from neighbouring geographical areas (e.g. Britain, 2002a, 2002b ; Trudgill, 1974, 1986).

\section{Origins of the features}

61 No study seems to corroborate the hypothesis of the influence of the media in situations where change affects phonological systems (Stuart-Smith \& Timmins, 2005). The attitude tests carried out in NWY (section 2), however, seem to shed a measure of light on the RP hypothesis and that of the influence of neighbouring areas.

Fig. 19 and 20 show how the informants in the over-50 and the 9-to-15 age bracket respectively rated 13 audio samples ${ }^{28}$ featuring 11 different accents of British English. The names at the bottom of the chart refer to the accents of the performers in the audio clips. RP1 and RP2 designate two samples featuring the voices of two RP speakers whose idiolects differed in some minor respects. London 1 and London 2 designate two samples featuring the voice of two performers whose accents, both distinctively London (although 
not Cockney), differed in some minor respects. The numbers on the vertical axis of the charts are the mean scores attributed to each accent by the informants. In answer to the question, "Do you like this accent ?" the informants were asked to choose between four possible answers : a) Yes, quite a lot; b) Yes, moderately ; c) No, not too much ; and d) No, not at all. A score of 0 was systematically attributed to each answer d); 1 to each answer c) ; 2 to each answer b) ; and 3 to each answer a). The charts thus feature the global score out of 3 attributed to each sample in the two age groups, and makes it possible to see how the accents in the samples rated in the 'absolute' judgment of the informants as well as relative to the other accents. ${ }^{29}$ The different colours used in fig. 19 and fig. 20 have no referential significance.

The charts testify to the difference of attitude towards RP in the 9-to- 15 and the over-50 bracket. The rather favourable rating and ranking of the RP idiolects in the over-50 bracket (with RP1 coming first) suggest that older speakers, who have been taught to regard RP as the standard of correctness, still have some form of respect for it. The medium rating of the two RP idiolects in the 9-to-15 age bracket (just above 1.5 out of 3 ) and its ranking towards the middle of the other accents suggest that for the teenage respondents, RP is but an accent among others. While this in itself is no positive evidence that RP does not exert any influence on NWY adolescents, such attitudinal considerations make it less likely that it should play any major part in accent change in the groups surveyed.

Fig 19 : Ratings of the samples by the informers in the over-50 age group

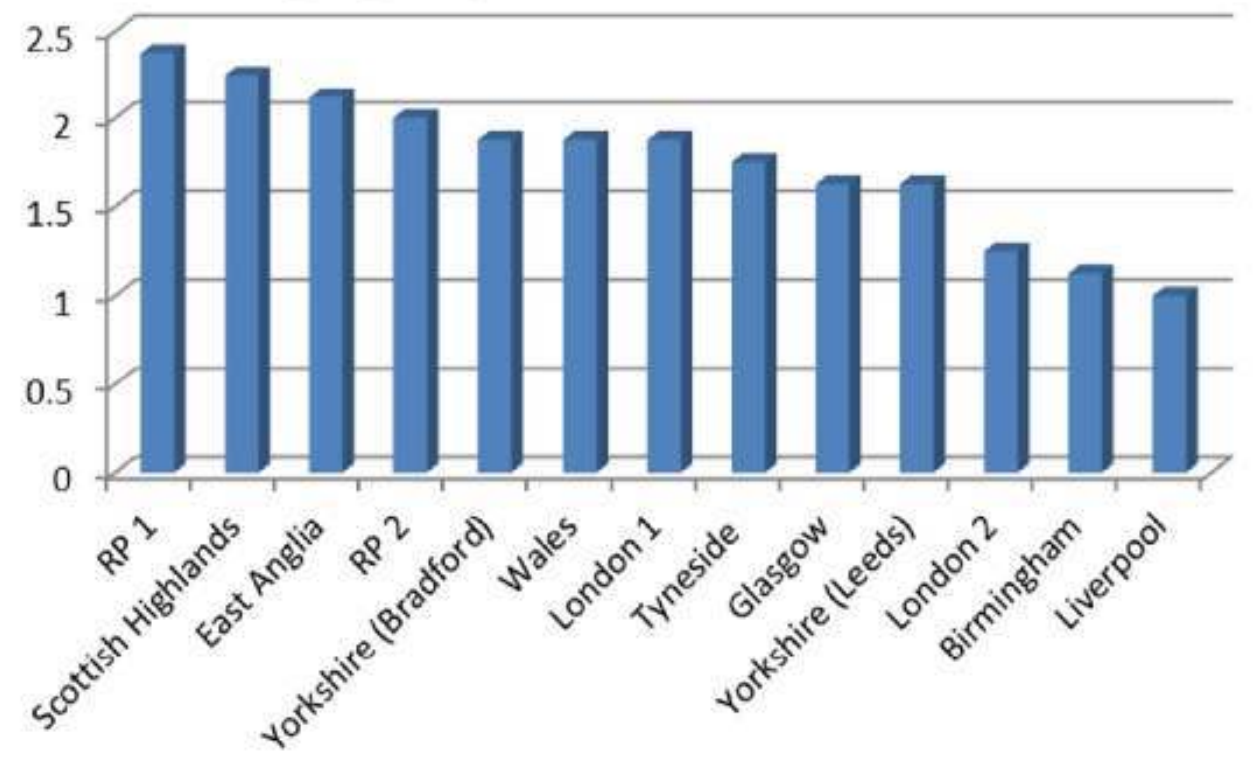




\section{Fig 20: Ratings of the samples by the informer 9-to-15 age group था}

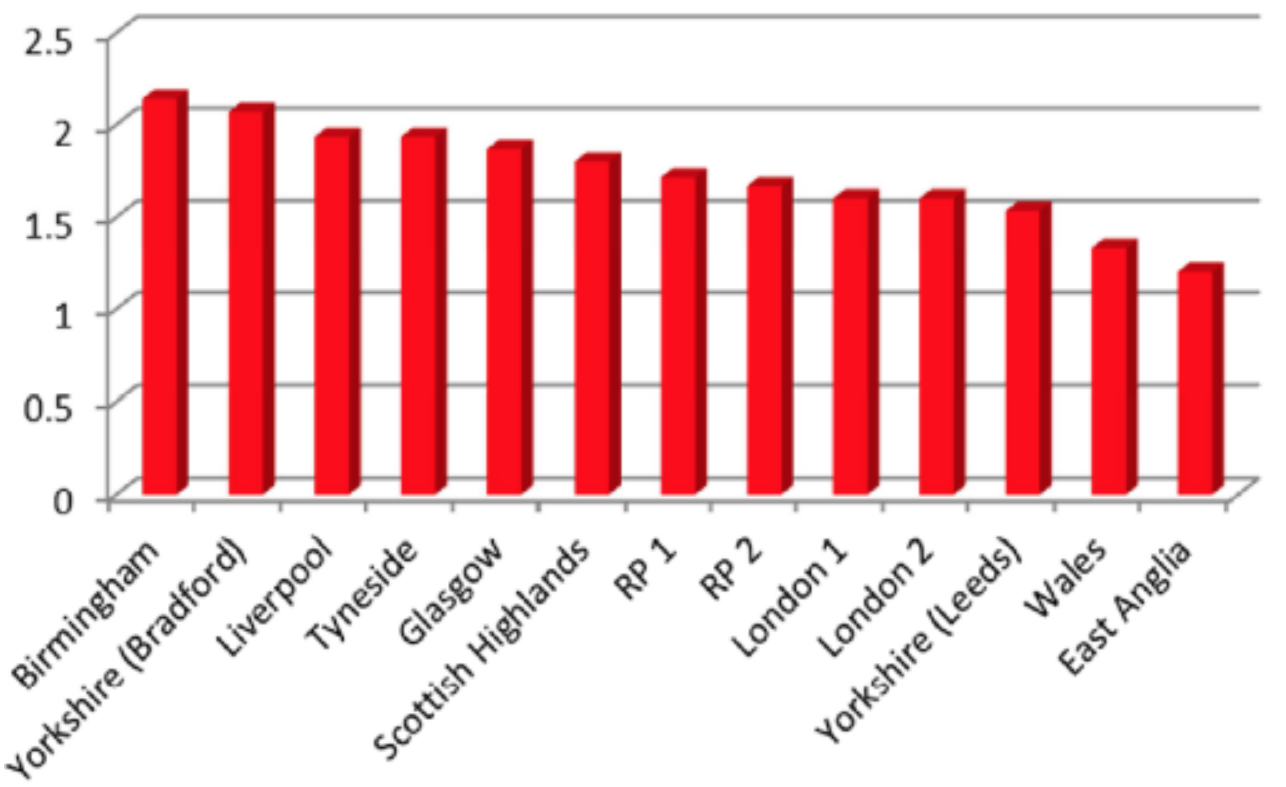

More striking is the information conveyed by the charts in connection with the attitudes of the informants towards urban northern British accents. Whereas the informers in the over-50 age group systematically ranked the accents of Liverpool, Birmingham, Glasgow and Tyneside at the bottom end of the attitude questionnaire, the adolescents consistently placed them at the top of their preference list, although they associated them with a number of conceivably negative traits (section 2), such as 'harsh/offensive', ' unintelligent' and 'unfriendly'. ${ }^{30} \mathrm{~A}$ possible explanation for these seemingly paradoxical findings may be that NWY adolescents, liable to construct social identities through opposition processes (Auer $2007: 13$ ), endeavour to differentiate themselves from older speakers by performing 'acts of identity' (Le Page, in Auer, $2007: 3-5$ ) through the use of urban northern British features, even though they perceive them as unpleasant in some respects.

Whereas, as appears supra, all the urban northern accents presented to the informants tend to be perceived favourably in the 9-to-15 bracket, only the Liverpool and Tyneside accents were correctly identified. This leads us to hypothesise that the influence of Scouse and Geordie could extend as far as NWY through the complex processes involved in geographical diffusion. ${ }^{31}$ The presence of segmental and suprasegmental features like fricated preaspirated K (also observed in Liverpool English [Watson, 2007 : 352]) and more recently in Lancashire (Kerswill, personal communication) as well as other areas in the North West of England (Hejná 2014 ; Hejná [forthcoming]), velarised voice (a prominent feature of Scouse (Knowles, 1975)), and UNBI rises (observed in Merseyside (Cruttenden, 1994 ; Knowles, 1975, 1978)) could even lend additional credence to the hypothesis of a Liverpool influence. ${ }^{32}$

Fig. $21^{33}$ shows the National Health Service Central Register (NHSCR) figures for migration movements from West Yorkshire Metropolitan County ${ }^{34}$ to the major regions in the 
United Kingdom in $2010^{35}$. According to these figures, the most likely destinations for internal migrants from West Yorkshire Metropolitan County are the remainder of Yorkshire and the Humber (that is the area comprising South Yorkshire Metropolitan County, East Riding, North Yorkshire and South Humber) (12,740 moves in 2010), and the North West region (9,720 moves in 2010).

Fig. 21 - NHSCR figures for migration movements from West Yorkshire Metropolitan County to major regions in the UK during the year ending December 2010

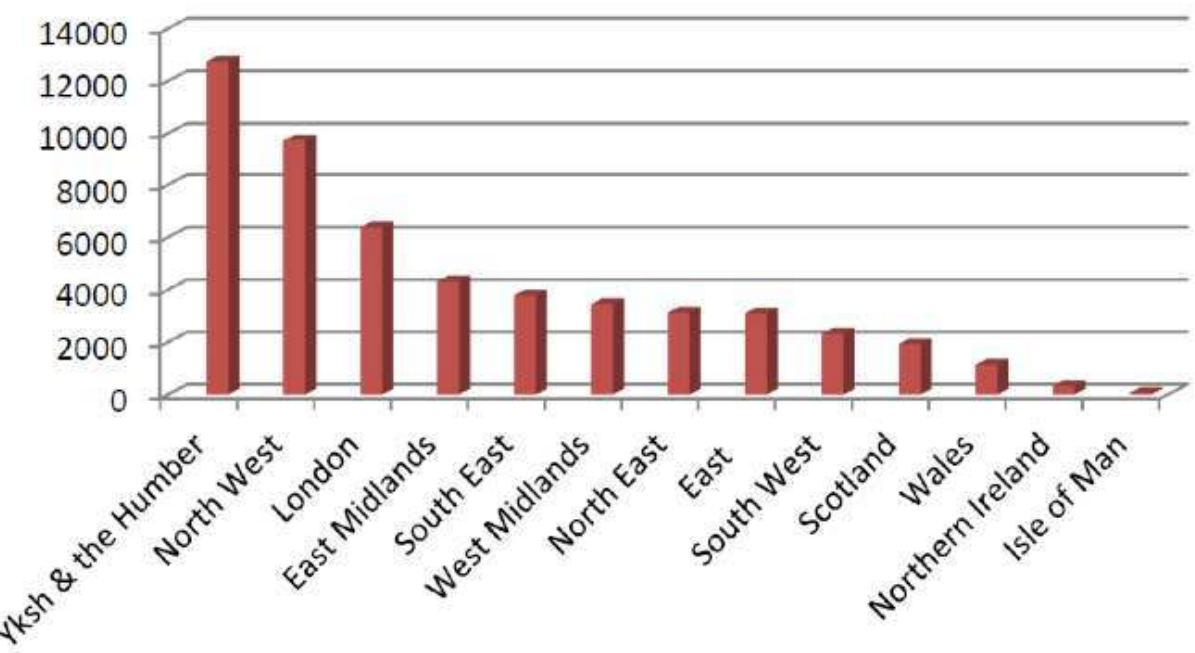

67 Fig. $22^{36}$ shows the National Health Service Central Register (NHSCR) figures for migration movements from Merseyside (county) to major regions in the United Kingdom and other locations in the North West in $2010^{37}$. According to the NHSCR figures (fig. 22), the most likely destinations for internal migrants from Merseyside are the counties of Cheshire (4,190 moves in 2010), Greater Manchester (3,640 moves in 2010) and Lancashire (2,890 moves in 2010), all located in the North West region ; and Yorkshire and the Humber $(2,360$ moves in 2010). The remainder of the North West and Yorkshire are thus the most likely destinations for internal migrants from Merseyside. According to additional National Statistics data for 2010, of all the counties comprising Yorkshire and the Humber, West Yorkshire Metropolitan County is by far the most likely destination for migrants from Merseyside $^{38}$. 
Fig. 22 - NHSCR figures for migration movements from Merseyside to major regions in the UK and other locations in the North West in $\mathbf{2 0 1 0}$

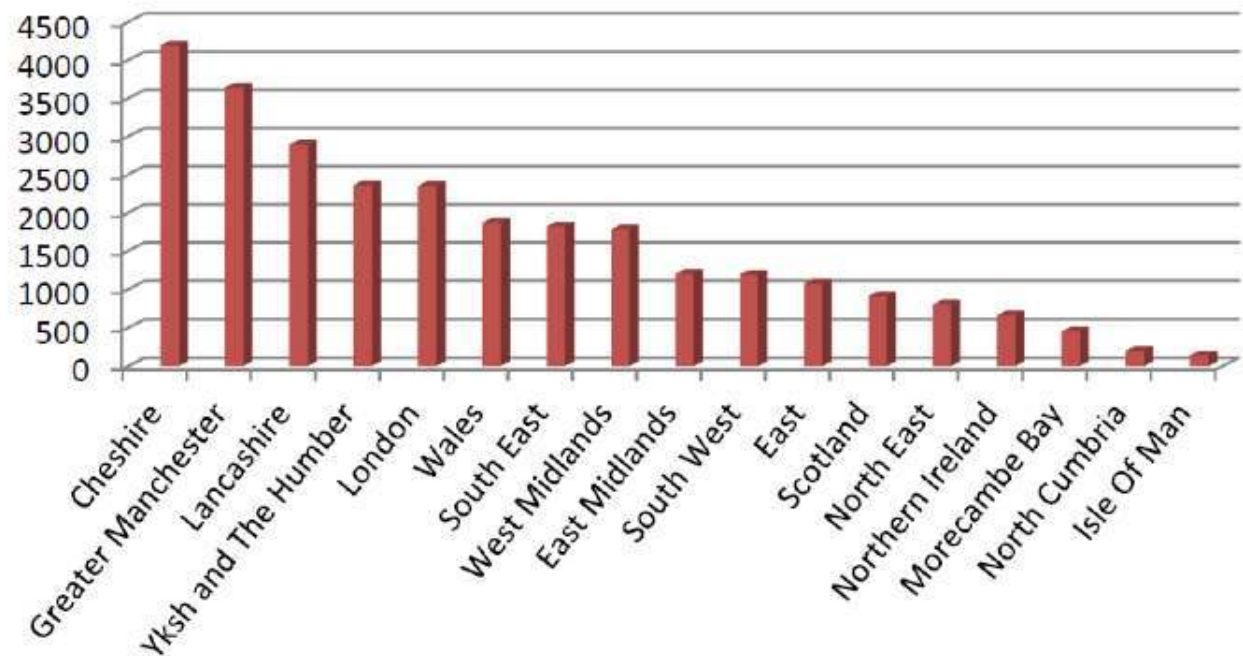

These data show that population shifts between West Yorkshire and the North West are comparatively substantial. They also show that the North West and Yorkshire and the Humber are the two major destinations for migrants from Merseyside, and that Yorkshire and the Humber and the North West are the most likely destinations for internal migrants from West Yorkshire Metropolitan County. All this might point to the development of a supralocal linguistic region in the north-west of England, and in no way detracts from the hypothesis of a Liverpool influence in the north-west, as far as NWY.

\section{Dialect levelling or geographical diffusion?}

Except in the case of a number of specific phenomena often commented on in the literature (happy tensing, GOOSE fronting or, more recently, GOAT fronting in the north of England), it is commonly reckoned that vowel change usually results from levelling rather than spatial diffusion, whereas it is generally the consonants that act as the 'torchbearers of geographical diffusion' (Kerswill, $2003: 231$ ).

The consonantal innovations reported in NWY are thus probably the outcome of geographical diffusion. The same is conceivably true of happy tensing, which, a few years ago, was still largely absent from most Yorkshire accents (Foulkes, personal communication). It may, however, prove harder to determine if the progress of diphthongal variants of FACE and GOAT or of PRICE diphthongs with short onsets is to be attributed to dialect levelling or diffusion. If, as suggested by Kerswill (personal communication), these variants turn out to be restricted to middle-class speakers, their presence in the 9-to-15 age group most probably results from diffusion phenomena. Yet their vigorous progression in apparent time seems to indicate that their monophthongal counterparts, 'marked variants' in the overall context of contemporary England, may well become minority features in NWY, soon to be levelled out. Besides, levelling, which can be observed on a wide scale, also has localized or 'regional' manifestations (Kerswill, $2003: 224$ ), and the spread of certain features within a regional community sometimes causes the forms which they replace to become 'marked variants' likely to recede over time (Kerswill, 2003) ${ }^{39}$. 
71 Again, some of the changes could testify to the formation of a supralocal linguistic area somewhere in the north-west of England, whereas the emergence of a number of specific feature $\mathrm{s}^{40}$ in an area comprising Tyneside, Humberside and Teesside (e.g. Watt \& Milroy, 1999 : 27-46 ; Watt \& Tillotson, $2001: 296$; Williams \& Kerswill, 1999 : 143) could signal the development of another supralocal region in the north-east. (This suggestion is based on a remark made by Joan Beal at the $5^{\text {th }}$ Northern Englishes Conference in Nottingham.)

\section{Language change in NWY - realisational or phonological ?}

72 This final section discusses some of the implications of the phonetic/phonological status of the changes observed in NWY. The first step in doing so consists in determining whether the innovations described above affect only isolated elements of phonemic systems that have remained unchanged, or if they point to deeper variations in NWY phonological inventories.

\section{Segmentals}

73 At the segmental level, most of the consonantal innovations observed in NWY would seem to be phonetic - that is, realisational - rather than phonemic, or phonological. Rlabiodentalisation, for instance, or the affrication of $\mathrm{K}$ do not lead to the emergence of contrastive pairs. By contrast, the attrition of levelled out vowels points to changes in NWY vocalic systems induced by simplification in a general context of supralocal koineisation (Kerswill, 2002b). ${ }^{41}$

\section{Suprasegmentals}

74 The question of the realisational vs. phonological status of suprasegmental elements is only relevant from an intonational point of view, there being no recognized phonological units of voice quality in English.

\section{- The spread of HRTs}

Most intonationists agree that, in Britain at least, the use of HRTs is stylistic rather than systemic (e.g. Cruttenden, $1986: 168-170$ ). This means that a speaker's decision to use HRTs instead of intonational falls is a matter of choice, and that the same statement uttered with a fall or an HRT retains the same basic 'meaning', except that a grammatical ('querying' - cf. 3.2.2), attitudinal or discoursal nuance is superimposed onto the statement featuring the HRT. ${ }^{42}$ This means that no systematic alteration of the traditional correspondences between intonational patterns and meaning is involved in the changes observed in NWY.

The full rise, however, does not belong to the 'traditional' list of NWY contours, which does have phonemic consequences since its usage enlarges the tone inventory of NWY accents. The spread of HRTs to NWY may thus be said to have phonological implications. ${ }^{43}$

\section{- UNBI tones}

Contrary to HRTs, UNBI rises or rise-slumps appear to be used systemically in a number of British locations (Cruttenden, 1994:170-171; Ladd, 1996:124-125, 144-145, 
$2008: 126-127)$. They are described as the unmarked tones for statements in UNBI (Ladd, 1996 : 123). Cruttenden (2001b:57, $2007: 258,270-271)$ also suggests that the variation observed between these patterns and simple falls at the end of statements in some northern British cities testifies to UNBI being used in alternation with RPI. If that is the case, UNBI rises testify to the co-occurrence of two distinct intonational systems and have phonological status.

This observation raises a number of questions. For instance, if NWY speakers really use two intonation systems in alternation, why is the same phenomenon not observed at the segmental level $?^{44}$ Why would speakers in Belfast or Glasgow use UNBI consistently and avoid RPI or Standard Scottish Intonation $?^{45}$ And why would speakers in other urban northern British areas switch from one code to another without any apparent reason? Cruttenden (2001:57), quoting Gumperz (1976), suggests that the motivation for alternating between two distinct intonation systems could be the wish to switch codes. This harks back to the complex debate on the functions of code switching. ${ }^{46}$ Again, part of the explanation may be that UNBI rises, like other features originating from urban northern cities, have an indexical function in some sort of role-play activity in which teenagers attempt to differentiate themselves from other speakers, whom they negatively associate with 'mainstream societal values' (cf. Chambers \& Trudgill, 1986:77-79). Adolescents could thus be seen as performing 'acts of identity' (cf. section 4.1.1; Auer, $2007: 4-8,13)$ involving the use of one or several salient features of other urban northern varieties.

\section{Conclusion}

This survey shows that NWY speech is characterised not only by distinct vocalic and consonantal features, but also by a number of suprasegmental traits. In terms of voice quality, for instance, NWY accents are characterised by a low setting of the tongue-body and by frequent and marked use of creaky voice. A similar methodology might profitably be extended to all accents of English, and it seems reasonable to suppose that it could also usefully be applied to other languages.

81 Several innovations and changes are observed in apparent time at both segmental and suprasegmental level. The data testifies to the attrition of some traditional phonemic contrasts in the vocalic system of NWY accents and to diverse modifications affecting the phonetic realisation of vocalic and consonantal phonemes. These are particularly salient in the production of young speakers. In terms of articulatory settings, permanent or intermittent use of velarised voice seems to be an innovative feature favoured by teenagers. Rising intonation patterns, unreported in traditional descriptions of Yorkshire accents, are also observed extensively at the end of statements in adolescent speech and, to a lesser extent, in other age brackets. Not all the rises belong to the same category while some are HRTs, others testify to the presence of UNBI, and some of the rises remain difficult to categorise. These findings show the need to further investigate the progress of HRTs and UNBI in the north of Britain as well as the functions and meanings of the tone inventory components of northern British accents. The fact that adolescents could be the main vectors of change confirms the observations already made by several sociolinguists (e.g. Chambers \& Trudgill, $1986: 77-79$ ) and possibly points to their usage of linguistic features to construct a social identity in opposition to older speakers. 

levels may result from geographical diffusion from other prominent urban northern areas, in particular Merseyside, thus testifying to the formation of new supralocal linguistic regions in the north-west of England. While dialect levelling and geographical diffusion have already been the objects of extensive study, some of the other issues raised here remain largely undocumented. This is true, for instance, of the voice-quality component of geographical or social accents, despite pioneering research by Barbera \& Barth (2007), Coadou (2007), Knowles (1975), or Stuart-Smith (1999). Similarly, although the need to explore the geographical, pragmatic and phonetic dimensions of UNBI has been identified for some time now, little progress has been achieved in these areas (Cruttenden, 1997:178-179, $2007: 272$ ). This article contributes to adding to the current database of variation in British English, and it is hoped that it will be useful in expanding the understanding of the mechanisms that operate in accent change. Throughout this paper, our aim has been to highlight the need to investigate research domains which have hitherto remained unexplored and encourage further work in the highly complex and multifaceted field of accent studies.

\section{BIBLIOGRAPHY}

Auer, Peter (1995). “The pragmatics of code-switching : A sequential approach.” In L. Milroy, P. Muysken (Eds.), One speaker two languages : Cross-disciplinary perspectives on code-switching. Cambridge : Cambridge University Press. 115-135.

Auer, Peter (1988a). “A conversation analytic approach to code-switching.” In M. Heller (Ed.), Code-switching : Anthropological and sociolinguistic perspectives. Berlin : Mouton de Gruyter. 187-214.

Auer, Peter (1998b). "From Code-switching via Language Mixing to Fused Lects : Toward a Dynamic Typology of Bilingual Speech." Interaction and Linguistic Structures $6: 1-28$.

Auer, Peter (2007). Style and Social Identities : Alternative Approaches to Linguistic Heterogeneity. Berlin : Mouton de Gruyter.

Barbera, Massimiliano, \& Barth, Marlen (2007). "A Scouse voice ? Harsh and unfriendly !” Phonetic clues to the perception of voice quality in Liverpool English. Studi Linguistici e Filologici Online vol. 5, $1: 51-83$.

Barry, Angela (2008). The Form, Function And Distribution of High Rising Intonation. Saarbrücken : Verlag Dr Müller. 
Beal, Joan (2004). "English dialects in the North of England : phonology." In B. Kortmann \& E. W. Schneider (Eds.), Handbook of Varieties of English : a Multimedia Reference Tool. vol. 1. Phonology. Berlin/New York : Mouton de Gruyter. 113-133.

Bradford, Barbara (1997). “Upspeak in British English.” English Today 51, 13.3 : 33-36. Reprinted in B.S. Collins, \& I.M. Mees (Eds.), Practical Phonetics and Phonology (2003). London : Routledge. 229-234.

Boersma, Paul \& Weenink, David (2006). Praat : doing phonetics by computer [Computer program]. < http://www.praat.org> (last accessed 16/09/2015).

Britain, David (1992). "Linguistic Change in Intonation : the use of High Rising Terminals in New Zealand English." Language Variation and Change 4 : 77-104.

Britain, David (1998). "High Rising Terminals in New Zealand English : Who uses them, when and why ?" Essex Research reports in Linguistics 21/09/98 : 33-58.

Britain, David (2002a). “Surviving 'Estuary English' : innovation diffusion, koineisation and local dialect differentiation in the British Fenland." Essex Research Reports in Linguistics 41 : 74-103.

Britain, David (2002b). "One foot in the grave ? Dialect death, dialect contact and dialect birth in England." International Journal of the Sociology of Language $41: 42-73$.

Britain, David (2010). “Supralocal regional dialect levelling." In C. Llamas, \& D. Watt., (eds.), Language and Identities. Edinburgh : Edinburgh University Press. 192-204.

Chambers, John Kenneth, \& Trudgill, Peter (1998 [1979]). Language in the British Isles (2 ${ }^{\text {nd }}$ ed.). Cambridge : Cambridge University Press.

Chevillet, François (1986). «Un exemple de complexité systémique dans la phonologie du Yorkshire. » In M. Cling \& J. Humbley (Eds.), Troisième colloque d'avril sur l'anglais oral de Villetaneuse : De la communication à la théorie. Université Paris-Nord. 217-242.

Ching, Marvin (1982). “The Question Intonation in assertions.” American Speech 57 : 95-107.

Coadou, Marion (2007). Qualité de voix et accents régionaux en anglais britannique. Doctoral dissertation, Université de Provence, Aix-en-Provence.

Cruttenden, Alan (1981). Falls and rises : meanings and universals. Journal of Linguistics $17 / 1: 77-92$.

Cruttenden, Alan (1994). "Rises in English." In J. Windsor Lewis (Ed.), Studies in General and English Phonetics : Essays in Honour of Professor J. D O'Connor. London : Routledge. 155-173.

Cruttenden, Alan (1997). Intonation (2nd Edition). Cambridge : Cambridge University Press.

Cruttenden, Alan (2001a). Gimson's Pronunciation of English. London : Routledge.

Cruttenden, Alan (2001b). "Mancunian intonation and intonational representation." Phonetica $58: 53-80$.

Cruttenden, Alan (2007). "Intonational diglossia : a case study of Glasgow." Journal of the International Phonetic Association. vol. 37, 3 : 257-274.

Docherty, Gerard, \& Foulkes, Paul (1999). “Derby and Newcastle : instrumental phonetics and variationist studies." In P. Foulkes G. Docherty (Eds.), Urban Voices (Accent Studies in the British Isles). London : Arnold. 47-71.

Ferguson, Charles Albert. (1959). “Diglossia.” Word 15 : 325-40.

Fishman, Joshua (1967). "Bilingualism with and without Diglossia ; Diglossia with and without Bilingualism." Journal of Social Issues 23(2) : 29-38. 
Foulkes, Paul (2002). “Current trends in British sociophonetics.” University of Pennsylvania Working Papers in Linguistics 8.3 - A Selection of Papers from NWAV $30: 75-86$.

Foulkes, Paul, \& Docherty, Gerard (1999). Urban Voices (Accent Studies in the British Isles). London : Arnold.

Giles, Howard, \& St. Clair, Robert (1979). Language and Social Psychology. London : Blackwell. Grabe, Esther (2002). "Variation adds to prosodic typology.” In B. Bel \& I. Marlin (Eds.), Proceedings of the Speech Prosody 2002 Conference, 11-13 April 2002. Aix-en-Provence : Laboratoire Parole et Langage. 127-132.

Grabe, Esther (2004). "Intonational variation in urban dialects of English spoken in the British Isles.” In P. Gilles \& J. Peters (Eds.), Regional Variation in Intonation. Linguistische Arbeiten. Tuebingen : Niemeyer. 9-31.

Grabe, Esther, Kochanski, Greg, \& Coleman, John (2005). "The intonation of native accent varieties in the British Isles - potential for miscommunication?” In K. Dziubalska-Kolaczyk \& P. Przedlacka (Eds.), English pronunciation models : a changing scene. Linguistic Insights Series. Oxford : Peter Lang.

Grabe, Esther, \& Nolan, Francis (1997-2002). IViE Corpus. Department of Linguistics, Oxford University : <http://www.phon.ox.ac.uk/files/apps/IViE//> (last accessed 16/09/2015).

Grabe, Esther, \& Post, Brechtje (2002). “Intonational Variation in English.” In B. Bel \& I. Marlin (Eds.), Proceedings of the Speech Prosody 2002 Conference, 11-13 April 2002. Aix-en-Provence : Laboratoire Parole et Langage. 343-346.

Gumperz, John Joseph (1976). The sociolinguistic significance of conversational code-switching. University of California Working Papers 46. CA : University of California.

Gumperz, John Joseph (1982). Discourse Strategies. Cambridge : Cambridge University Press. Guy, Gregory, Horvath, Barbara, Vonwiller, Julia, Daisley, Elaine, \& Rogers, Inge (1986). “An intonation change in progress in Australian English." Language in Society 15 : 23-52.

Hejná, Míša (2014). “Pre-aspiration in Wales and England”. Linguist Mix UG/PGR enhancement lecture series, University of Manchester, Manchester, UK ; a talk given to BA students : <https:// misprdlina.files.wordpress.com/2013/06/pre-aspiration-in-wales-and-england1.pdf> (last accessed 16/09/2015).

Hejná, Míša (Forthcoming). “Does English pre-aspiration matter ?”

Hejná, Míša \& Scanlon, Jane (Forthcoming). “New Laryngeal Allophony in Manchester English.”

Henton, Caroline, \& Bladon, Anthony (1988). “Creak as a sociophonetic marker.” In L.M. Hyman \& C.N. Li (Eds.), Language, Speech and Mind : Studies in honour of Victoria A. New York and London : Routledge.

Howse, Geoffrey (2014). The Little Book of Yorkshire. Stroud : The History Press, Ltd.

Jarman, Eric, \& Cruttenden, Alan (1976). Belfast intonation and the myth of the fall. Journal of the International Phonetic Association $6: 4-12$.

Johnson, Wyn, \& Britain David (2004). L Vocalisation as a naturally occurring phenomenon. Essex Research Reports in Linguistics 44 : 1-37.

Jones, Mark (1999). The phonology of definite article reduction. Leeds Studies in English $30: 103-122$. 
Jones, Mark (2002). The origin of definite article reduction in Northern English dialects : evidence from dialect allomorphy. English Language- and Linguistics 6 : 325-145.

Jones, William (1952). The definite article in living Yorkshire dialect. Leeds Studies in English 7-8 : 81-91.

Kerswill, Paul (2002a). Koineisation and Accommodation. J.K. Chambers, P. Trudgill, \& N. Schilling-Estes (Eds.), The Handbook of Language Variation and Change. London : Blackwell. 669-702. Kerswill, Paul (2002b). Models of linguistic change and diffusion : new evidence from dialect levelling in British English. Reading working papers in linguistics 6 : 187-216.

Kerswill, Paul (2003). Dialect levelling and geographical diffusion in British English. D. Britain \& J. Cheshire (Eds.), Social Dialectology. Amsterdam : John Benjamins. 223-243.

Kerswill, Paul, \& Williams, Ann. (2000). “'Salience' as an explanatory factor in language change : evidence from dialect levelling in urban England", Reading Working Papers in Linguistics 4, 63-94.

Knowles, Gerry (1975). Scouse : the spoken dialect of Liverpool. Doctoral dissertation. University of Leeds.

Knowles, Gerry (1978). The nature of phonological variables in Scouse. In P. Trudgill (Ed.), Sociolinguistic patterns in British English. London : Arnold : 80-90.

Labov, William (1972). Sociolinguistic patterns. Philadelphia, PA : University of Pennsylvania Press. Labov, William (1994). Principles of Linguistic Change. vol. 1 : Internal Factors. Oxford : Blackwell. Labov, William (2001). Principles of Linguistic change. vol. 2 : Social Factors. Oxford : Blackwell. Labov, William (2010). Principles of Linguistic change. vol. 3 : Cognitive and Cultural Factors. Oxford : Blackwell.

Ladd, David Robert (1996). Intonational phonology (Cambridge Studies in Linguistics 79). Cambridge : Cambridge University Press.

Ladd, David Robert (2008). Intonational phonology (Second edition, Cambridge Studies in Linguistics 119). Cambridge : Cambridge University Press.

Laver, John (1980). The Phonetic description of voice quality. Cambridge : Cambridge University Press.

Laver, John (1994). Principles of phonetics. Cambridge : Cambridge University Press.

Laver, John, Wirz, Sheila, Mackenzie, Janet, \& Hiller, Steven (1985). Vocal profile analysis in the description of voice quality. In V. Lawrence (Ed.), Transactions of the 14th Symposium on the Care of the Professional Voice. New York: The Voice Foundation. 184-192.

Laver, John, Wirz, Sheila, Mackenzie, Janet, \& Hiller, Steven (1991). A perceptual protocol for the analysis of vocal profiles. In J. Laver (Ed.), The Gift of Speech : Readings in the analysis of speech and voice. Edinburgh : Edinburgh University Press. 265-280.

Liberman, Mark (2006a). Angry rises. Language Log, 11/02/2006 : <http://itre.cis.upenn.edu/ $\sim$ myl/languagelog/archives/002823.html> (last accessed 16/09/2015).

Mackenzie Beck, Janet (2005). Perceptual analysis of voice quality : the place of Vocal Profile Analysis. In W.J. Hardcastle \& J.M. Mackenzie Beck (Eds.), A Figure of Speech : a Festschrift for John Laver. London : Laurence Erlbaum. 285-322.

Marasek, Krzysztof. (1997) EGG and Voici quality. Thèse de doctorat non publiée. University of Stuttgart : <www.ims.uni-stuttgart.de/EGG/> (last accessed 05/06/2017). 
Mayo, Catherine (1996). Prosodic transcription of Glasgow English : an evaluation study of GlaToBI. Master's thesis. University of Edinburgh.

Mondada, Lorenza (2007). Le code-switching comme ressource pour l'organisation de la paroleen-interaction. Journal of language contact $1: 168-197$.

Nilep, Cheb (2006). Code Switching in Sociocultural Linguistics. Sociocultural Linguistics Colorado Research in Linguistics $19:$ <http://colorado.edu/ling/CRIL/Vo-lume19_Issue1/paper_NILEP.pdf $>$ (last accessed 27/08/2012).

Ohala, John, J. (1983). “The phonological end justifies any means”, in K. Inoue and S. Hattori (eds.), Proceedings of the XIIIth International Congress of Linguists, Tokyo, 29 Aug.- 4 Sept. 1982, edited and distributed by Sanseido Shoten, Tokyo, 232-243.

Petyt, Keith Malcolm (1985). Dialect and accent in Industrial West Yorkshire. Amsterdam/ Philadelphia : John Benjamins.

Siegel, Jeff. (1985). “Koines and koineisation”, Language in Society 14, 357-78.

Stuart-Smith, Jane (1999). Glasgow : accent and voice quality. In P. Foulkes \& G. Docherty (Eds.), Urban Voices (Accent Studies in the British Isles). London : Arnold : 203-222.

Stuart-Smith, Jane, Timmins, Claire, \& Tweedie, Fiona (2004). Conservation and innovation in a traditional dialect : L-vocalisation in Glaswegian. English World Wide 27 : 71-87.

Stuart-Smith, Jane, \& Timmins, Claire (2005). Is television a contributory factor in accent change in adolescents? Final report on ESRC Grant no. R000239575.

Stuart-Smith, Jane, Timmins, Claire, \& Tweedie, Fiona (2007). ‘Talkin' Jockney’ ?, Variation and change in Glaswegian accent. Journal of Sociolinguistics 11/2:221-260.

Trudgill, Peter (1974). The Social Differentiation of English in Norwich. Cambridge : Cambridge University Press.

Trudgill, Peter (1986). Dialects in Contact. Oxford : Blackwell.

Trudgill, Peter (1999). Norwich : endogenous and exogenous linguistic change. In P. Foulkes \& G. Docherty (Eds.), Urban Voices (Accent Studies in the British Isles). London : Arnold. 124-140.

Trudgill, Peter (2001). Sociolinguistic Variation and Change. Edinburgh : Edinburgh University Press. Wales, Katie (2006). Northern English, a cultural and social history. Cambridge : Cambridge University Press.

Wardhaugh, Ronald (2010). An introduction to sociolinguistics. Malden, Massachusetts : WileyBlackwell.

Watson, Kevin (2007). Liverpool English. Journal of the International Phonetics Association $37 / 3: 351-360$.

Watt, Dominic, \& Milroy, Leslie (1999). Patterns of variation and change in three Newcastle vowels : is this dialect levelling. In P. Foulkes \& G. Docherty (Eds), Urban Voices (Accent Studies in the British Isles). London : Arnold. 25-46.

Watt, Dominic, \& Tillotson, Jennifer (2001). A spectrographic analysis of vowel fronting in Bradford English. English World-Wide 22(2) : 269-302.

Wells, John Christopher (1982). Accents of English 1 : An Introduction. Cambridge : Cambridge University Press. 
Wells, John. Christopher (1982). Accents of English 2 : The British Isles. Cambridge : Cambridge University Press.

Wilhelm, Stephan (2005). Accent change in the British Isles : the four dimensions of an invisible hand. M.A. dissertation. Université de Nancy 2.

Wilhelm, Stephan (2011). Innovations segmentales et suprasegmentales dans le NW Yorkshire : Implications pour l'étude du changement accentuel dans l'anglais des îles Britanniques. Doctoral dissertation. University of Burgundy.

Wilhelm, Stephan (2015). "Urban North British Intonation - Le système intonatif des accents de l'anglais du nord du Royaume-Uni." In Actes du Colloque du 17 mai 2014. Paris : Les Amis du Crelingua. 72-88.

Williams, Ann, \& Kerswill, Paul (1999). Dialect levelling : change and continuity in Milton Keynes, Reading and Hull. In P. Foulkes \& G. Docherty (Eds.), Urban Voices (Accent Studies in the British Isles). London : Arnold. 141-162.

Zribi-Hertz, Anne (2011). Pour un modèle diglossique de description du français : quelques implications théoriques, didactiques et méthodologiques. Journal of French Language Studies. vol. 21, 2 : 231-256.

\section{NOTES}

1. Cf. section 4.1.1.

2. < http://www.accentbank.co.uk/>. The Accent Bank website hosts a variety of audio clips featuring the voices of performers from diverse parts of the United Kingdom.

3. Lexically restricted variants of the PRICE and GOAT vowels (e.g. in I, my, coat, coal, hole, etc. (Chevillet, 1986:228; Wells, 1982:358) and Definite Article Reduction or DAR (W. Jones, $1952: 81-91$; M. Jones, $1999: 103-22$; $2002: 325-45$; Wales, $2006: 31,51,61,197$ ) were considered to fall outside the scope of this article and were not taken into consideration.

4. Some degree of variation is nevertheless observed in STRUT, where contrasts somewhat inconsistently occur between $[\underset{\nabla}{]}]$ and $[\gamma] \sim[\ddot{\gamma}]$ or even $[3]$ in the speech of some informants. Chevillet (1986:222-223) and Wells (1982:351-353) attribute this to the influence of RP. Petyt (1985: 110-117, 341) seems to share this view.

5. Wells (1982) - Tape accompanying the $1^{\text {st }}$ edition of Accents of English.

6. Innovative suprasegmental features are examined in section 3.1.2.

7. See, however, note 24 .

8. This is understandable as far as GOAT is concerned, given that the THOUGHT vowel is normally very open and leaves room for open realisations of the close-mid back rounded vowel.

9. Cp. Chevillet, $1986: 225$.

10. All long vowels show a tendency to diphthongisation. In most accents of English, this seems to be particularly the case for the FLEECE vowel (Cruttenden, 2001a : 105). In the charts used here, we have chosen to number the high vowels among the pure vowels insofar as they are traditionally considered as phonological monophthongs (cf. e.g. Cruttenden 2001).

11. '[T] dimensions of vocoid space. In this respect, the speaker's articulatory setting is the joint outcome of the location in vocoid space of the different vocoids and their frequency of occurrence. These two factors combine to determine the centre of gravity of the speaker's vocoid distribution.' (Laver, 1994 : 404) Cf. also Stuart-Smith (1999 : 203-222). 
12. Creaky voice is produced by the combination of strong adduction and very weak longitudinal tension of the vocal folds, which causes the phonatory apparatus to thicken and vibrate slowly and irregularly. In creaky voice, the subglottal air pressure and glottal airflow are also weaker than in modal voice.

13. MAIN is here defined as a subset of FACE comprising words spelt with $<\mathrm{ai}>$ or $<\mathrm{ei}>$, traditionally realised with /ei/. By contrast, words in the MANE subset, spelt with $<\mathrm{a}>+\mathrm{C}+$ word-final $<\mathrm{e}>$, are, or were, traditionally realised with /e:/ ([e:] [ë:] $\sim[\varepsilon:])$ (Chevillet, 1986: 225-226; Wells, $1982: 357-364)$.

14. KNOWs is here defined as a subset of GOAT mostly comprising words spelt with <ow>, traditionally realised with /ov/. By contrast, words in the NOSE subset, spelt with $<0>+C+$ wordfinal <e>, are traditionally realised with /o: / (Chevillet, $1986: 225-226$; Wells, $1982: 357-364$ ).

15. MEET is here defined as a subset of FLEECE mostly comprising words spelt with <ee>, traditionally realised with / $\varepsilon \mathrm{i} /$. By contrast, words in the MEAT subset, spelt with <ea>, were traditionally realised with /i:/ (Chevillet, $1986: 225-226$; Wells, $1982: 357-364$ ).

16. There seems, however, to be a WAIT/WEIGHT contrast in the production of some of the informants who have monophthongal variants of FACE. WAIT is here defined as a lexical subset of FACE comprising most WAIT words (cf. footnote 16) except those which once had a velar fricative, like eight, weight, neigh, etc., subsumed in the WEIGHT subset (cf. Wells, 1982 : 357).

17. No statistically significant variation is observed according to sex or class, although Kerswill (personal communication) suggests that a larger corpus may have yielded evidence that class was a determining factor.

18. This testifies to the spread of a phenomenon known as GOAT fronting, observed in Tyneside, Humberside, Teesside and, more recently, Bradford (Watt \& Tillotson, 2001).

19. Word-final L is sometimes realised as a close-mid vocoid $([\gamma])$ or as a continuation of the preceding vowel (e.g. football ['fo?bo::]; schools: ['skọ:z]). Central vocoids are sometimes observed word-internally, where a clear lateral approximant would have been expected: e.g. really $=>$ ['viə⿱઼i, ; feel free $=>$ ['fịฺ 'f

20. In most cases, intermittent velarisation was triggered by the use of a word-initial velar L, e.g. I wonder if Oliver's got one of those comby things... Oh there's loads of people then I've seen with Afro - I saw someone walking round Bradford, and they had the comb stuck in their Afros. => [a w

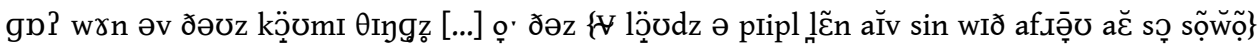

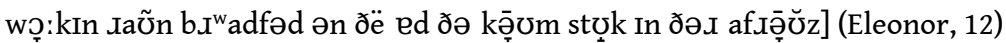

21. Except for a brief remark on Leeds intonation in Wales $(2006: 202)$ to the effect that ' $[r]$ ising tones are now also a distinctive feature of urban West Yorkshire speech, e.g. Leeds.'

22. These appear to be salient insofar as, during informal exchanges, several informants testified to their being upset by NWY teenagers 'always saying things as if they were asking questions'.

23. In connection with somewhat similar contours observed in Glasgow, Cruttenden $(2007: 264)$ remarks that 'the query appears to be of a very general nature: something like 'Are you following me ?').

24. Depending on the degree of speaker involvement.

25. According to Cruttenden (1994:57, $2007: 258$ ), a 'slump' is distinguished from a 'fall' in that the pitch does not return to the low point where it left off at the beginning of the pattern. In the NWY data the slumping part of the rise-slumps usually spans a narrower range than observed by Cruttenden in Manchester (Cruttenden, 2001b) or in Glasgow (Cruttenden, 2007).

26. There do happen to be cases where discriminating between HRT and UNBI is not easy (Cruttenden, personal communication). Up to very recently, it was claimed that HRTs and UNBI rises were distinguishable on the basis of phonetic and functional criteria (Ladd, 1996 : 124-125). A close examination of the phonetics and pragmatics of HRTs and UNBI tones, however, invalidates this statement (Wilhelm, $2011: 388-408$ ). 
27. Wells (1982: 357) attributes the blurring of the distinction between MAIN/MANE and KNOWS/ NOSE to the influence of 'RP and other accents'.

28. Taken from the Accent Bank website (section 2).

29. For example, the charts show that the Scottish Highlands accent rated an average score of 2.25 out of 3 in the over-50 age bracket whereas its average score in the younger group is just below 2 ('absolute' rating). The Scottish Highlands accent ranks $2^{\text {nd }}$ out of 13 in the over-50 age bracket, but only $6^{\text {th }}$ out of 13 in the 9-to-15 age bracket (relative rating). There is thus no significant difference in the rating of the Scottish Highlands accent in the two groups, but there seems to be a difference in terms of popularity.

30. The same recurring traits tend to be associated with these accents by the adolescents, who generally judge them 'unaffected', 'animated/involved', 'streetwise', 'urban', 'modern' and 'tough', but also 'harsh/offensive' and 'unintelligent' as well as 'unfriendly'.

31. What is suggested is not that Liverpool or Newcastle exerts a direct influence over Leeds or rural locations in the Yorkshire Dales, but that through complex mechanisms, the linguistic influence of these two metropolitan areas may be felt at a considerable distance. Indeed, it is striking that, when discussing the spread of Estuary English, Trudgill (2001:178) describes these two very conurbations as major sources of linguistic (counter)influence in the north of England and considers that 'there is no way in which the influence of London is going to be able to counteract [their] influence.' Besides, in spite of the geographical remoteness of Hull and Newcastle, the presence of GOAT fronting (cf. footnote 21) in West Yorkshire cities testifies to the influence of Tyneside and Humberside (Beal, personal communication; Watt \& Tillotson, 2001 : 296)

32. Although referring to phenomena of a more local nature than that of those discussed in this article, Beal (2004:122) and Watson (2007) also comment on the diffusion of features from Liverpool to other areas in the North West of England.

33. Source: Office for National Statistics <http://www.ons.gov.uk/ons/publications/re-referencetables.html?edi-tion=tcm\%3A77-228332>.

34. Comprising the districts of Bradford, Calderdale and Kirklees, Leeds and Wakefield.

35. A comparison of NHSCR figures for interregional migration movements within the UK in the years ending December 2009, September 2010 and September 2011 suggests that the migration patterns remain largely the same from year to year (source: Office for National Statistics).

36. Source: Office for National Statistics <http://www.ons.gov.uk/ons/publications/re-referencetables.html?edition=tcm\%3A77-228332>. In fig.22, the figures for migration movements from Merseyside to the remainder of the North West have been broken up into figures for migration movements from Merseyside to the counties of Cheshire, Greater Manchester and Lancashire.

37. A comparison of NHSCR figures for interregional migration movements within the UK in the years ending December 2009, September 2010 and September 2011 (source : Office for National Statistics) shows that the migration patterns remain largely the same from year to year.

38. 1180 in 2010 as against 610 for South Yorkshire metropolitan county and 580 for the area comprising the counties of Yorkshire, East Riding and South Humber.

39. Yorkshire assimilation, a consonantal feature, might be retained not so much because of local speakers' attachment to it as a geographical marker as because it is relatively unsalient.

40. For instance, innovative monophthongal variants of FACE and GOAT (Watt \& Milroy, 1999) or glottalised realisations of $\mathrm{P}$ and $\mathrm{K}$, 'a distinguishing feature between the north-east and the north-west' (Jansen, personal communication).

41. Wells (1982 : 358) points out that the absence of MANE/MAINE and NOSE and KNOWS distinctions suggests that the close-mid mergers are now mostly completed in the Middle North as elsewhere in Britain. 
42. The question of the meaning(s) of HRTs has been hotly debated over the past two decades (e.g. Britain, 1992 ; Ching, 1982 ; Guy, Horvath, Vonwiller, Daisley, \& Rogers, 1986 ; Liberman, 2006a), and will not be discussed in detail here.

43. Besides these phonological considerations, the presence of the full rise alongside the low rise and the high rise poses a problem in terms of Tone and Break Index representation insofar as it becomes necessary to use an $\mathrm{M}$ tone to distinguish this contour from the two others (Cruttenden, $2007: 269)$. This violates one of the basic requirements of the ToBI system.

44. Wells (1982:351-352) actually suggests that the variable quality of the sTRUT vowels in northern accents of England is similarly to be traced to alternations between a 5- and a 6element system, owing to RP influence. It would be of interest to determine if the use of UNBI tones consistently coincides with that of STRUT variants.

45. It may be answered that in Belfast and other areas in Northern Ireland the intonation system is not in direct opposition with another intonation system comparable to that of RP. In Glasgow, Cruttenden (2007) identified a case of 'intonational diglossia'.

46. The motivations of code-switching and diglossia, a very similar phenomenon to situational code-switching, have been discussed by e.g. Auer (1995, 1998a, 1998b) ; Ferguson (1959) ; Fishman (1967); Mondada (2007); Nilep (2006); Wardhaugh (2010); Zribi-Hertz (2011) (Wilhelm, 2011 : 213-517).

\section{ABSTRACTS}

A number of phonetic and phonological changes have lately been observed in most geographical varieties of British English (e.g. Trudgill 1986 ; Foulkes \& Docherty 1999 ; Britain 2002b ; Kerswill 2003 ; Stuart-Smith et al. 2004, 2007). This phenomenon seems to have been accelerated in the past decades by increasing social and geographical mobility (e.g. Kerswill 2003; Britain 2002a, $2002 \mathrm{~b}$; Stuart-Smith et al. 2004).

Based on a corpus mainly composed of recordings of spontaneous conversations between native North West Yorkshire (NW Yorkshire) speakers divided into age groups, this paper identifies and analyses a number of segmental and suprasegmental innovations observed in apparent time in both urban and rural settings. It discusses the sociolinguistic motivation behind some of these innovations and addresses the question of whether the same factors and principles operate in suprasegmental change - especially in the fields of intonation and voice quality - as in the diffusion of non-traditional segmental phonetic/phonological features. It also tackles the nature and status of diffusing intonational patterns such as the innovative use of rising tones in association with statements. The semantic/pragmatic value of these patterns is taken into consideration as well as that of a number of articulatory and phonatory adjustments characterising adolescent speech. It is suggested that the changes observed occur as a result of koineisation and supralocalisation processes (Siegel 1985; Kerswill and Williams 2000 ; Britain 2005,2009 ), and that they testify to the emergence of new supralocal dialect areas in the north of England.

Divers changements de nature phonétique et phonologique ont récemment été observés dans de nombreuses variétés géographiques de l'anglais britannique (voir par exemple Trudgill 1986; Foulkes \& Docherty 1999; Britain 2002b; Kerswill 2003; Stuart-Smith et al. 2004, 2007. Ce phénomène semble s'être accentué au cours des dernières décennies en raison de l'accroissement 
de la mobilité sociale et géographique (voir par exemple Kerswill 2003 ; Britain 2002a, 2002b ; Stuart-Smith et al. 2004).

A partir d'un corpus majoritairement constitué d'enregistrements d'interactions spontanées entre locuteurs du nord-ouest du Yorkshire répartis en plusieurs groupes d'âges, nous identifions et analysons ici plusieurs changements segmentaux et suprasegmentaux observés en temps apparent en milieu rural et urbain. Nous nous interrogeons quant à la motivation sociolinguistique de ces évolutions et nous demandons si les mêmes facteurs et principes déterminent les changements observés au niveau phonémique et prosodique, particulièrement sur le plan de l'intonation et la qualité de voix. Nous nous intéressons notamment à la nature et au statut d'innovations intonatives telles que certains schémas ascendants observés en fin d'énoncé déclaratif. Nous proposons une réflexion sur la valeur sémantique et pragmatique de ces contours ainsi que sur le recours à des ajustements articulatoires caractéristiques attestés chez les adolescents. Nous suggérons que les changements recensés résultent de phénomènes de koinéisation et de supralocalisation (voir Siegel 1985 ; Kerswill and Williams 2000 ; Britain 2005, 2009) et que les données recueillies témoignent de la formation de nouvelles zones linguistiques dans le nord de l'Angleterre.

\section{INDEX}

Mots-clés: Anglais, sociolinguistique, variation, changement linguistique, prosodie, intonation, éléments suprasegmentaux, UNBI, qualité de voix, nivellement dialectal, diffusion géographique, supralocalisation, Yorkshire

Keywords: English, sociolinguistics, language variation and change, speech prosody, intonation, suprasegmentals, UNBI, voice quality, dialect levelling, geographical diffusion, supralocalisation, Yorkshire

\section{AUTHOR}

\section{STEPHAN WILHELM}

TIL - University of Burgundy

CPGE Lycée C.-L. Berthollet, Annecy

sbwilhelm@orange.fr 